Teka Kom. Hist. OL PAN-TN KUL, 2020, 2(17), 26-59

DOI: http://dx.doi.org/10.18290/teka.20.3

\title{
„CZARODZIEJ KLAWIATURY”W ŚWIECIE DYPLOMACJI \\ ROLA IGNACEGO JANA PADEREWSKIEGO \\ W WALCE O POLSKIE GRANICE (1919-1920)
}

\author{
Anna Krochmal \\ Naczelna Dyrekcja Archiwów Państwowych, Warszawa \\ The Head Office of State Archives, Warsaw \\ e-mail: akrochmal@archiwa.gov.pl
}

\begin{abstract}
Streszczenie. Ignacy Jan Paderewski (1860-1941) - światowej sławy pianista, kompozytor, polityk oraz mąż stanu i dyplomata odegrał znaczącą rolę w kształtowaniu się odrodzonego państwa polskiego i jego granic. Aktywną działalność polityczną podjął w okresie pierwszej wojny światowej. W latach 1915-1918 pozyskał dla sprawy polskiej prezydenta Stanów Zjednoczonych, Woodrowa Wilsona i jego najbliższe otoczenie polityczne oraz ponad 4-milionową Polonię amerykańską. Realny wpływ na kształtowanie się terytorium i granic państwa polskiego zyskał po objęciu urzędu premiera polskiego rządu i ministra spraw zagranicznych, co miało miejsce 16 stycznia 1919 r. Doprowadził on do uznania odrodzonego państwa polskiego na arenie międzynarodowej przez Stany Zjednoczone (30 stycznia 1919 r.), Francję (23 lutego), Wielką Brytanię (25 lutego), Włochy (27 lutego), a następnie inne państwa. Reprezentował Polskę w Paryżu jako delegat na konferencję pokojową. W trakcie kilku miesięcy obrad walczył o włączenie do państwa polskiego Galicji Wschodniej, Śląska Cieszyńskiego i Górnego Śląska oraz Gdańska wraz z Pomorzem. Wspierali go w tych działaniach znani polscy uczeni, zarówno historycy (Szymon Askenazy, Oskar Halecki, Władysław Konopczyński), jak i geografowie (Eugeniusz Romer). Razem z Romanem Dmowskim podpisał w Wersalu w dniu 28 czerwca 1919 r. traktat pokojowy kończący I wojnę światową. Po rezygnacji z funkcji premiera w dniu 9 grudnia 1919 r. i wyjeździe z kraju, nadal interesował się sprawami polskimi. Do działalności politycznej powrócił w okresie inwazji bolszewickiej na Polskę. Od lipca 1920 r. do maja 1921 r. był na prośbę rządu polskiego i naczelnika państwa Józefa Piłsudskiego polskim delegatem na konferencje międzynarodowe oraz przedstawicielem przy Lidze Narodów.
\end{abstract}

Słowa kluczowe: Ignacy Jan Paderewski; Konferencja pokojowa w Paryżu; traktat wersalski; powstania śląskie, Galicja Wschodnia; Śląsk Cieszyński; Górny Śląsk; Wolne Miasto Gdańsk.

W 2019 r. obchodzona była 100. rocznica objęcia urzędu premiera i ministra spraw zagranicznych przez Ignacego Jana Paderewskiego (1860-1941). Ten pochodzący z kresów dawnej Rzeczypospolitej światowej sławy pianista, kompozytor, 
polityk oraz mąż stanu i dyplomata pozostaje w cieniu innych znanych ojców polskiej niepodległości. Odegrał on jednak znaczącą rolę w kształtowaniu się odrodzonego państwa polskiego i jego granic.

Celem niniejszego artykułu jest przybliżenie niedocenianej na ogół i mało znanej roli Ignacego Jana Paderewskiego w walce politycznej i działaniach dyplomatycznych o uznanie odrodzonego państwa polskiego na arenie międzynarodowej, zapewnienie mu miejsca i znaczenia wśród narodów Europy i świata, jak też o uformowanie kształtu terytorialnego II Rzeczypospolitej. Działalność prowadzącą do zrealizowania wymienionych powyżej zadań podjął Paderewski już w latach I wojny światowej i kontynuował ją jako prezydent Rady Ministrów i minister spraw zagranicznych II RP w 1919 r. oraz jako delegat Polski na konferencję pokojową w Paryżu obradującą od stycznia do czerwca 1919 r.

Dotychczasowy dorobek historiograficzny, dotyczący różnych sfer życia i działalności Ignacego Jana Paderewskiego obejmuje przede wszystkim opracowania biograficzne powstałe po II wojnie światowej, autorstwa takich historyków jak Roman Wapiński ${ }^{1}$, Marian Marek Drozdowski ${ }^{2}$, Adam Zamoyski³ ${ }^{3}$ Henryk Lisiak ${ }^{4}$, Henryk Przybylski ${ }^{5}$. Krytycznego podejścia i konfrontacji z materiałem archiwalnym wymagają wcześniejsze biografie Paderewskiego, w większości wydane na emigracji, choć zawierają one szereg cennych informacji ${ }^{6}$. Wśród nich wyróżnia się jedno z pierwszych opracowań, napisane przez muzyka i wieloletniego znajomego oraz sąsiada Paderewskich w ich szwajcarskiej posiadłości, Henryka Opieńskiego ${ }^{7}$. Znaczną wartość poznawczą, choć obarczoną subiektywnym spojrzeniem, mają pamiętniki spisane za życia Paderewskiego, dyktowane przez niego angielskiej dziennikarce, Mary Lawton ${ }^{8}$. Bardzo cenną monografią jest książka Andrzeja Pibera,

1 R. WAPIŃSKI, Ignacy Paderewski, Wrocław 1999.

2 M.M. Drozdowski, Ignacy Jan Paderewski. Zarys biografii politycznej, wyd. 2 poprawione, Warszawa 1981. Zob. też: TENŻE, O niepodległa i demokratyczna Rzeczpospolita. Z dziejów aktywności artystycznej i obywatelskiej Ignacego Jana Paderewskiego, Kraków-Warszawa 2018; TENŻE, Paderewski w latach II wojny światowej, „Więź”, 1986, nr 5/6, s. 175-188.

3 A. ZAMOYSKI, Paderewski, Warszawa 1992.

4 H. Lisiak, Paderewski. Od Kurytówki po Arlington, Poznań 1992.

5 H. PrZYBYLSKI, Paderewski. Między muzyka a polityka, Katowice 1992.

6 Ch. Phillips, The Story of a Modern Immortal, New York 1933; R. LANDAu, Paderewski, London 1934, Warszawa 1935; J. ORıowski, Ignacy Jan Paderewski i odbudowa Polski, t. 1-2, Chicago 1939-1940; Cz. Halski, Ignacy Jan Paderewski. Dzieje wielkiego Polaka i wielkiego Europejczyka, London 1964.

7 H. OpIeŃsKi, Ignacy Jan Paderewski, Warszawa 1928. Równocześnie w Lozannie ukazała się wersja francuskojęzyczna tej książki, wznowiona w Szwajcarii w 1948 r. oraz w Polsce w 1964 r.

8 Wersja angielska wspomnień pt. The Paderewski Memoirs, spisanych przez M. Lawton, ukazała się w Londynie w wydawnictwie Collins w 1939 r. Polską wersję pamiętników opublikowało Polskie Wydawnictwo Muzyczne w 1984 r. 
pracownika Archiwum Akt Nowych, który przez wiele lat opracowywał spuściznę archiwalną Paderewskiego i głównie na niej oparł swoje studium obejmujące początkowy okres działalności artysty do 1901 r. ${ }^{9}$ Przed kilku laty wydano drukiem wspomnienia Heleny Paderewskiej, zachowane w rękopisie w Instytucie Hoovera w Stanford, w których autorka skoncentrowała swoją uwagę głównie na postaci Ignacego Paderewskiego oraz jego karierze artystycznej i politycznej w okresie 1910-1920 ${ }^{10}$. Duże znaczenie dla postępu w badaniach nad działalnością Paderewskiego miało opublikowanie 6-tomowego wydawnictwa źródłowego pt. Archiwum polityczne Ignacego Jana Paderewskiego, obejmującego głównie dokumenty z jego spuścizny zgromadzonej w willi Riond Bosson w Szwajcarii, które po II wojnie światowej trafiły do Archiwum Akt Nowych w Warszawie ${ }^{11}$. Wiele nowych wątków do biografii oraz działalności politycznej i kariery artystycznej wniosły opracowania Małgorzaty Perkowskiej-Waszek ${ }^{12}$. W ostatnich dwóch latach w ramach inicjatyw podejmowanych w związku ze 100-leciem odzyskania przez Polskę niepodległości wydano drukiem nowe cenne opracowania. Na uwagę zasługują m.in. listy Paderewskiego do ojca i żony Heleny ${ }^{13}$, publikacja poświęcona Paderewskiemu w Kalifornii ${ }^{14}$, czy też nowe opracowania podsumowujące rolę mistrza w odzyskiwaniu niepodległości ${ }^{15}$. Pojawiło się też kilka nowych wydawnictw albumowych, zawierających obok komentarzy obszerny materiał ilustracyjny z życia i działalności znanego artysty i polityka ${ }^{16}$. Wymienione powyżej publikacje ukazują różne aspekty

\footnotetext{
${ }^{9}$ A. Piber, Droga do stawy. Ignacy Paderewski w latach 1860-1902, Warszawa 1982.

${ }^{10}$ Helena Paderewska: Wspomnienia 1910-1920, oprac. M. Siekierski, Warszawa 2015.

${ }^{11}$ Archiwum polityczne Ignacego Paderewskiego, t. I: 18901918, oprac. W. Stankiewicz, A. Piber, Wrocław 1973; t. II: 191921, oprac. W. Stankiewicz, A. Piber, Wrocław 1974; t. III: 192134, oprac. H. Janowska i C. Madajczyk, Wrocław 1974; t. IV: 193540, oprac. T. Jędruszczak i A. Leinwand, Wrocław 1974; t. V: 1909-1941, wybór i oprac. A.G. Dąbrowski, M.M. Drozdowski (red. naukowy), K. JanczewskaSołomko, M. Perkowska-Waszek, X. Pilch, Warszawa 2001; t. VI: 1915-1941, oprac. A.G. Dąbrowski, M.M. Drozdowski (red. naukowy), M. Perkowska-Waszek, X. Pilch, Warszawa 2007.

12 M. Perkowska, Diariusz koncertowy Ignacego Jana Paderewskiego, Kraków 1990; M. PerkowSKA-WASZEK, Ignacy Jan Paderewski o sobie. Zarys biografii wzbogacony listami artysty, TarnówKąśna Dolna 2004; TAŻ, Za kulisami wielkiej kariery. Paderewski w dziennikach i listach Sylwina i Anieli Strakaczów 1936-1937, Kraków 1994; TAż, Paderewski i jego twórczość. Dzieje utworów i rys osobowości kompozytora, Kraków 2010.

${ }^{13}$ Ignacy Jan Paderewski. Listy do Ojca i Heleny Górskiej (1872-1924), oprac. M. Perkowska-Waszek, red. M. Sułek, J. Szombara, Warszawa 2018.

${ }^{14}$ M. Żebrowski, Paderewski w Kalifornii, Toruń 2018.

${ }^{15}$ M.M. Drozdowski, Ignacy Jan Paderewski - wspóttwórca Niepodległej, Warszawa 2017; TENŻE, O niepodległa i demokratyczna Rzeczpospolita. Z dziejów aktywności artystycznej i obywatelskiej Ignacego Jana Paderewskiego, Kraków-Warszawa 2018.

${ }^{16}$ Paderewski. Anatomia geniuszu. Warszawa 2018; Paderewski. Katalog wystawy, Muzeum Narodowe w Warszawie, 17 lutego - 20 maja 2018, red. J. Bojarska-Cieślik, M. Pinker, J. Popkowska,
} 
wszechstronnej działalności Paderewskiego oraz jej znaczenie dla najnowszej historii Polski.

Do podjęcia na nowo badań nad tą wyjątkową w dziejach Polski postacią skłania ogromny zasób dokumentów archiwalnych zachowany do dnia dzisiejszego, nie w pełni wykorzystany w dotychczasowej literaturze przedmiotu. Spuścizna dokumentacyjna Paderewskiego to jedno z największych archiwów osobistych tej rangi postaci ${ }^{17}$. Równocześnie jest jednym z najbardziej rozproszonych archiwów prywatnych, przechowywanym obecnie w ponad dwudziestu archiwach i instytucjach pamięci na terenie Polski ${ }^{18}$, Francji ${ }^{19}$, Stanów Zjednoczonych ${ }^{20}$, Szwajcariii ${ }^{21}$, Ukrainy ${ }^{22}$ i Wielkiej Brytanii ${ }^{23}$. Największą wartość poznawczą mają źródła tworzone przez ponad 40 lat w szwajcarskiej posiadłości Paderewskiego Riond Bosson na przedmieściach Morges. Większość z nich jest obecnie przechowywana w Archiwum Akt Nowych w Warszawie ${ }^{24}$.

Warszawa 2018; M. OlCzAK, Ignacy Jan Paderewski 1860-1941, Warszawa 2018; A. Krochmal, Król pianistów w świecie polityki. Ignacy Jan Paderewski w dokumentach archiwalnych, Warszawa 2019.

${ }^{17}$ Szczegółowo na temat narastania spuścizny Paderewskiego, jej losów i zawartości zob. A. КROCHMAL, Król pianistów w świecie polityki, s. 159-191.

${ }^{18}$ Główna część spuścizny znajduje się w Archiwum Akt Nowych w Warszawie. Jej fragmenty przechowują też: Archiwum Narodowe w Krakowie, Archiwum Państwowe w Gdańsku, Archiwum Państwowe w Poznaniu, Archiwum Państwowe w Warszawie, Narodowe Archiwum Cyfrowe, Biblioteka Narodowa w Warszawie, Muzeum Narodowe w Warszawie, Narodowy Instytut Fryderyka Chopina w Warszawie, Ośrodek Dokumentacji Muzyki Polskiej XIX i XX w. im. I.J. Paderewskiego w Krakowie, Centrum Paderewskiego w Kąśnej Dolnej.

${ }^{19}$ W Bibliotece Polskiej w Paryżu zachował się m.in. zbiór map, na których pracowała polska delegacja na konferencję pokojową w Paryżu oraz inne materiały po działalności Ignacego Jana Paderewskiego.

${ }^{20}$ Najważniejsze fragmenty spuścizny przechowują obecnie instytucje polonijne: Polish Music Center w Los Angeles, Muzeum Polskie w Ameryce (z siedzibą w Chicago), Instytut Józefa Piłsudskiego w Ameryce (z siedzibą w Nowym Jorku), Stowarzyszenie Weteranów Armii Polskiej w Ameryce (z siedzibą w Nowym Jorku), Polski Instytut Naukowy w Ameryce (z siedzibą w Nowym Jorku). Część materiałów źródłowych, w tym fotografie zachowały się w zbiorach Biblioteki Kongresu w Waszyngtonie oraz Instytutu Hoovera w Stanford.

${ }^{21}$ Materiały związane z życiem i działalnością Paderewskiego przechowują: Archiwum Fundacji Helveto-Polonicum we Fryburgu, Polska Misja Katolicka w Marly pod Fryburgiem, Muzeum Polskie w Rapperswilu, Muzeum Paderewskiego w Morges.

${ }^{22}$ Najważniejsze znaczenie mają dokumenty zachowane w Archiwum Państwowym Obwodu Żytomierskiego w Żytomierzu, zesp. nr 146. Zob. Державний архів Житомирської области. Анотований реєстр описів. Фонди дворянського періоду, Житомир 2009, s. 65-66.

${ }^{23}$ Dokumenty dotyczące działalności Paderewskiego we Froncie Morges oraz z okresu II wojny światowej, w tym materiały filmowe i fotograficzne znajdują się w Instytucie Polskim i Muzeum im. gen. Sikorskiego w Londynie.

${ }^{24}$ A. PIBER, Archiwum Ignacego Jana Paderewskiego, „Archeion”, t. XXXIX, 1963, s. 63-86; R. GóRSKI, Archiwum Ignacego Jana Paderewskiego. Proces aktotwórczy i archiwizacja, „Teki Archiwalne. 
Początki kariery politycznej Paderewskiego wiążą się z jego udziałem w obchodach 500-lecia bitwy pod Grunwaldem, zorganizowanych w Krakowie w lipcu 1910 r. ${ }^{25}$ Wzięło w nich udział ponad 150 tys. osób, przybyłych z wszystkich trzech zaborów, jak też z ośrodków polonijnych w Stanach Zjednoczonych. Płomienne przemówienie wygłoszone przez Paderewskiego 15 lipca podczas uroczystego odsłonięcia pomnika grunwaldzkiego wzniesionego z funduszy artysty stało się nie tylko patriotyczną manifestacją narodu polskiego, lecz także początkiem politycznego zaangażowania światowej sławy pianisty w działania na rzecz odbudowy niepodległego państwa polskiego ${ }^{26}$. W okresie I wojny światowej Paderewski umiejętnie wykorzystał oszałamiającą karierę artystyczną i swoją popularność wśród tysięcy fanów w Europie, a zwłaszcza w Ameryce Północnej do budzenia świadomości narodowej ponad 4-milionowej Polonii amerykańskiej oraz budowania poparcia dla sprawy polskiej wśród politycznych elit amerykańskich. Wiosną 1915 r. artysta udał się w najdłużej trwającą podróż do Stanów Zjednoczonych (ponad 3,5 roku), w czasie której wygłosił ponad 300 przemówień, zagrał kilkaset koncertów, odwiedził najważniejsze ośrodki polonijne, zebrał ogromne fundusze na wsparcie polskich ofiar wojny, doprowadził do utworzenia Armii Polskiej u boku zachodnich aliantów, a przede wszystkim pozyskał dla sprawy polskiej najpierw najbliższe otoczenie prezydenta USA, Woodrowa Wilsona, a później także jego samego. Dzięki wytężonej pracy Paderewskiego, jego bliskim kontaktom z amerykańskim sekretarzem stanu Robertem Lansingiem oraz doradcą prezydenta Stanów Zjednoczonych płk. Edwardem House’em, jak też bezpośrednim spotkaniom z prezydentem Wilsonem możliwe stało się umiędzynarodowienie sprawy polskiej. Memoriały na temat historii i sytuacji ziem polskich napisane przez Paderewskiego i przekazane prezydentowi Wilsonowi w 1917 r. posłużyły do ostatecznego sformułowania programu pokojowego, ogłoszonego w orędziu Wilsona do Kongresu Stanów Zjednoczonych 8 stycznia $1918 \mathrm{r}^{27} \mathrm{~W}$ punkcie 13 . tego dokumentu zapowiadano utworzenie

Seria Nowa", t. 11(33), 2011, s. 345-362; A. DĄBRowski, Archiwum Ignacego Jana Paderewskiego z lat 1861-1941 przechowywane w zasobie Archiwum Akt Nowych - tekst dostępny online na stronie: http://cennebezcenne.pl/wp-content/uploads/2018/05/DABROWSKI-www.pdf

${ }^{25}$ Dokumentacja tych uroczystości zachowała się w Archiwum Narodowym w Krakowie [dalej: ANK], zespół 670, Zbiór Fotograficzny, sygn. 6082, 7846.

${ }^{26}$ Treść przemówienia w Archiwum Akt Nowych [dalej: AAN], zespół nr 100, Archiwum Ignacego Jana Paderewskiego [dalej: AIJP], sygn. 609, s. 30-33. Przemówienie opublikowano w: Archiwum polityczne Ignacego Paderewskiego, t. I, s. 27-28 oraz Ignacy Jan Paderewski. Myśli o Polsce i Polonii, red. M.M. Drozdowski, A. Piber, Paris 1992, s. 58-59.

${ }^{27}$ Tekst memoriału Paderewskiego w języku angielskim zachowany w dwóch wersjach znajduje się w AAN, AIJP, sygn. 592, s. 7-35 - wersja w rękopisie; tamże, s. 36-54, 74-84 - wersja w maszynopisie z poprawkami Paderewskiego. Maszynopis memoriału został opublikowany w: Archiwum 
niepodległego państwa polskiego z dostępem do morza. Program ten był realizacją koncepcji głoszonej przez Paderewskiego od wybuchu I wojny światowej, mówiącej o konieczności zjednoczenia ziem polskich wszystkich trzech zaborów, w tym włączenia do odbudowanego państwa polskiego Gdańska ${ }^{28}$. Miasto to uważał Paderewski za kluczowe dla interesów polskich, swoiste „okno, bez którego Polska nie mogłaby oddychać" 29 . Jako dziecko z dawnych kresów Rzeczypospolitej marzył o odbudowie Polski w granicach przedrozbiorowych. Będąc realistą politycznym zdawał sobie jednak sprawę z nieodwracalnych przemian, które się dokonały na ziemiach polskich przez ponad stulecie i konieczności uwzględnienia interesów innych narodów w sytuacji zaistniałej w Europie po 1918 r.

Realny wpływ na kształtowanie się terytorium i granic państwa polskiego zyskał Paderewski po powrocie ze Stanów Zjednoczonych do kraju, co nastąpiło w grudniu 1918 r. Droga powrotna wiodła przez Wielką Brytanię do Gdańska, a następnie Poznania. Została ona świadomie wybrana przez Paderewskiego, aby podkreślić symboliczne znaczenie dla sprawy polskiej miejsc, przez które przejeżdżał w drodze do Warszawy. Przyjazd do Gdańska odbył się na pokładzie brytyjskiego krążownika „Concord” w dniu 25 grudnia 1918 r. Dzień później Paderewski wyruszył do Poznania, w którym jego krótki pobyt i wygłoszone patriotyczne przemówienie stały się sygnałem do wszczęcia antyniemieckiego powstania ${ }^{30}$. Działania militarne zakończone sukcesem w lutym 1919 r. były ważnym argumentem, który wykorzystał Paderewski na konferencji pokojowej w Paryżu do uzyskania od aliantów decyzji potwierdzającej przyłączenie Wielkopolski do odrodzonego państwa polskiego.

polityczne Ignacego Paderewskiego, t. I, s. 100-112. W 2014 r. memoriał został wpisany na Krajową Listę Programu UNESCO „Pamięć Świata”. Zob. https://pamiecpolski.archiwa.gov.pl/memorialignacego-jana-paderewskiego/

${ }^{28}$ AAN, AIJP, sygn. 667, s. 83-89, Przemówienie Paderewskiego na zebraniu Narodowej Ligi Bezpieczeństwa o Armii Polskiej i sprawie granic przyszłego państwa polskiego, Nowy Jork, 3 marzec 1918 r.; wersja publikowana dokumentu: Archiwum polityczne Ignacego Paderewskiego, t. I, s. 298-303.

${ }^{29}$ AAN, AIJP, sygn. 841, s. 2-3, Projekt oświadczenia Paderewskiego w sprawie Gdańska, złożony na posiedzeniu Rady Najwyższej, Paryż, 9 kwietnia 1919 r. Dokument opublikowany w: Archiwum polityczne Ignacego Paderewskiego, t. I, s. 86-87.

${ }^{30}$ Materiały ikonograficzne dotyczące przyjazdu Paderewskiego do Poznania zachowały się w AAN, AIJP, sygn.745 oraz w Archiwum Państwowym w Poznaniu. Zob. zesp. 4807, Stanisław Nawrocki spuścizna, sygn. 600, 1252, 1276, 1277; zesp. 4046, Zbiór pocztówek, sygn. 216. W tej samej instytucji przechowywane są najważniejsze dokumenty dotyczące wybuchu i przebiegu powstania wielkopolskiego, które są dostępne również online na stronie: http://archiwumpowstania.pl/pl/. Wymienione archiwalia w 2018 r. zostały wpisane na Listę Krajową Programu UNESCO „Pamięć Świata”. Zob. http://poznan.ap.gov.pl/zasob-2/dokumenty-powstania-wielkopolskiego/. O roli Paderewskiego w wybuchu powstania wielkopolskiego zob. D. SzymczaK, Najważniejszy gość Bazaru. Paderewski, Bazar i powstanie wielkopolskie, „Kronika Miasta Poznania”, 2015, nr 4, s. 140-158. 
Podobnie entuzjastyczne powitanie zgotowała Paderewskiemu Warszawa w dniu jego przyjazdu 2 stycznia $1919 \mathrm{r}^{31} \mathrm{~W}$ swoim pierwszym przemówieniu wygłoszonym z Hotelu Bristol Paderewski deklarował: „Nie przyszedłem po dostojeństwa, sławę, zaszczyty, lecz aby służyć, ale nie jakiemuś stronnictwu. Szanuję wszystkie stronnictwa, lecz nie będę należał do żadnego. Stronnictwo powinno być jedno: Polska, i temu jednemu stużyć będę do śmierci”32. Rozmowy prowadzone z naczelnikiem państwa Piłsudskim doprowadziły do powołania rządu jedności narodowej w targanym sporami politycznymi państwie ${ }^{33}$. W dniu 16 stycznia 1919 r. Piłsudski akceptował skład Rady Ministrów z Paderewskim na czele, któremu powierzył także tekę ministra spraw zagranicznych i funkcję delegata Polski na konferencję pokojową w Paryżu ${ }^{34}$. Nowy rząd miał charakter ponadpartyjny. Premier Paderewski doprowadził do zjednoczenia politycznego i scalenia dwóch ośrodków władzy działającego w Paryżu Komitetu Narodowego Polskiego z Romanem Dmowskim na czele oraz ośrodka władzy w Warszawie, kierowanego przez Józefa Piłsudskiego. Akt zgody narodowej był szeroko popierany przez wszystkie siły polityczne i społeczeństwo, o czym pisał Eugeniusz Romer: „Wiara w Paderewskiego jako tej potęgi z nieba dla zjednoczenia umysłów w Polsce zesłanej, jako niezawodnego łącznika Polski z ententą, której łaski i względy ku Polsce zwróci, wiara w ententy moc a moc prawa, była w Polsce wprost mistyczna" ${ }^{\text {"35 }}$.

Cieszący się zaufaniem przywódców mocarstw zachodnich nowy premier szybko doprowadził do uznania Polski za niepodległe państwo, sprzymierzone z koalicją. Jako pierwsze uczyniły to Stany Zjednoczone (30 stycznia 1919 r.),

${ }^{31}$ AAN, AIJP, sygn. 793, s. 17-18; Fotografia z powitania Paderewskich na dworcu w Warszawie, zob. M.M. DrozDowski, Ignacy Jan Paderewski. Zarys biografii politycznej, Warszawa 1981, fot. nr 70.

${ }^{32}$ A. ZAMoYski, Paderewski, s. 192.

${ }^{33}$ Przerwał je na krótko nieudolnie przygotowany zamach stanu skierowany przeciwko rządowi socjalisty Jędrzeja Moraczewskiego, planowany z nocy z 4 na 5 stycznia. W ciągu kilku godzin Piłsudski opanował sytuację w mieście i wysłał do Krakowa swojego przedstawiciela w osobie gen. Stanisława Szeptyckiego z zaproszeniem dla Paderewskiego do powrotu do stolicy i kontynuowania rozmów o uformowaniu nowego rządu. 6 stycznia doszło do ponownego spotkania obu polityków, a w kolejnych dniach do uzgodnienia szczegółów porozumienia.

${ }^{34}$ Szczegółowo na temat działalności rządu Paderewskiego zob.: J. Goclon, Paderewski jako Prezes Rady Ministrów (16 stycznia - 9 grudnia 1919), „Czasopismo Prawno-Historyczne”, 63(2011), z. 1, s. 221-245; TENŻE, Rząd Ignacego Paderewskiego. Geneza, skład osobowy i działalność (16 stycznia 1919 - 9 grudnia 1919), „Acta Universitatis Lodziensis”, Folia Historica 86, 2011, s. 94-145; TENŻE, Próby reform i dokonania gabinetu Ignacego Paderewskiego w świetle protokołów posiedzeń Rady Ministrów (16 stycznia - 9 grudnia 1919 r.), cz. 1, „Słupskie Studia Historyczne” 2015, nr 19, s. 133-171; W. Suleja, Ignacy Jan Paderewski, premier Republiki Polskiej 16 I- 9 XII 1919, w: Prezydenci i premierzy Drugiej Rzeczypospolitej, red. A. Chojnowski, P. Wróbel, Wrocław 1992.

${ }^{35}$ Eugeniusz Romer, Pamiętnik paryski (1918-1919), oprac. A. Garlicki, R. Świętek, WrocławWarszawa-Kraków 1989, s. 120. 
po nich Francja (23 lutego), Wielka Brytania (25 lutego) i Włochy (27 lutego). Był to pierwszy sukces nowego rządu w polityce zagranicznej. W zasługi Paderewskiego w tym procesie nie wątpiło przedstawicielstwo Polonii amerykańskiej. W dniu 31 stycznia 1919 r. prezes Wydziału Narodowego Polskiego, głównej organizacji polskiej w Chicago, Jan Smulski, skierował list gratulacyjny do Paderewskiego, w którym pisał: „Wiadomość o uznaniu Rządu Polskiego utworzonego przez drogiego Pana przez Stany Zjednoczone nadeszła dzisiaj. Jesteśmy do głębi duszy przejęci tą wiadomością. Wiemy czyja to głównie zasługa, zasyłamy więc drogiemu Panu nasz hołd, nasze uznanie, nasze serdeczne przywiązanie" ${ }^{36}$. Uznanie Polski przez państwa zachodnie miało ogromne znaczenie nie tylko dla pozycji negocjacyjnej na rozpoczynającej się w styczniu 1919 r. konferencji pokojowej w Paryżu, lecz także dla sytuacji wewnętrznej odradzającego się państwa. Na kilka dni przed objęciem urzędu premiera przez Paderewskiego, gen. Stanisław Szeptycki, szef Sztabu Generalnego Wojsk Polskich, w liście do naczelnika Piłsudskiego alarmował, że sytuacja armii polskiej jest rozpaczliwa, a stojące przed nią wyzwania ogromne. Do priorytetowych zadań zaliczał: zorganizowanie odsieczy dla Lwowa i obrona ziem polskich w Galicji Wschodniej, ustalenie granic na Wołyniu oraz Śląsku, Orawie i Spiszu, wsparcie wyzwalających się o własnych siłach Wielkopolski, Śląska i Prus Zachodnich (Pomorza Gdańskiego). Przestrzegał równocześnie przed zbliżającą się przez ziemie litewskie i białoruskie falą bolszewizmu, zwłaszcza po zajęciu przez Armię Sowiecką Wilna. Wskazywał na fakt, że wszelkie starania o pomoc u państw Ententy spełzły na niczym wobec jej nieufności do rządu socjalisty Jędrzeja Moraczewskiego (,,jest ona głucha na nasze prośby i przedstawienia uważając dzisiejszy Rząd jako ekspozyturę bolszewizmu") ${ }^{37}$.

Objęcie steru rządów w Polsce przez Paderewskiego zapewniło nie tylko polityczne poparcie ze strony mocarstw, lecz uruchomiło też ogromną pomoc amerykańską i dostawy środków żywnościowych i artykułów pierwszej potrzeby dla setek tysięcy osób ${ }^{38}$.

${ }^{36}$ AAN, AIJP, sygn. 995, s. 50.

${ }^{37}$ AAN, AIJP, sygn. 745, s. 32-34, List gen. Stanisława Szeptyckiego Szefa Sztabu Generalnego Wojsk Polskich do Naczelnika Państwa Józefa Piłsudskiego w sprawie organizacji i zadań armii polskiej w związku z sytuacją międzynarodową Polski, 10 stycznia 1919 r. Treść tego listu zachowana także w Archiwum Instytutu Józefa Piłsudskiego w Nowym Jorku, zesp. nr 2, Adiutantura Generalna Naczelnego Wodza, sygn. 3, s. 45-47. Dokument opublikowano w: Sprawy polskie na konferencji pokojowej w Paryżu 1919. Dokumenty i materiały, red. R. Bierzanek, J. Kukułka, t. III, Warszawa 1968, s. 227-230.

${ }^{38}$ Organizatorem pomocy humanitarnej był stojący na czele Amerykańskiej Administracji Pomocy Herbert Hoover, późniejszy prezydent USA. Zob. AAN, AIJP, sygn. 987-988. Fotografie z wizyty Hoovera w Warszawie w 1919 r. w Narodowym Archiwum Cyfrowym [dalej: NAC], zesp. Koncern Ilustrowany Kurier Codzienny - Archiwum ilustracji, sygn. 1553. Na zdjęciach obok Hoovera widoczni Józef Piłsudski, Ignacy Jan Paderewski oraz inni przedstawiciele władz polskich. 
Przed gabinetem Paderewskiego stanęło następnie główne wyzwanie, któremu poświęcił kilka miesięcy urzędowania. Było nim doprowadzenie do podpisania korzystnego dla Polski traktatu pokojowego na konferencji paryskiej i ustalenie ostatecznego kształtu terytorialnego państwa. Cel ten realizowany był zarówno w drodze walki zbrojnej, jak też poprzez działania dyplomatyczne. Paderewski angażował się przede wszystkim w te drugie, uważając konflikty militarne za zło konieczne. Kierowanie podejmowanymi akcjami wojskowymi pozostawało w rękach naczelnika państwa, Józefa Piłsudskiego.

W chwili objęcia gabinetu przez Paderewskiego państwo polskie znajdowało się w sporze terytorialnym niemal ze wszystkimi swoimi sąsiadami. Na wschodzie kraju od listopada 1918 r. toczyła się wojna polsko-ukraińska o Galicję Wschodnią. Nieustalony był odcinek północno-wschodni granicy (z ziemiami białoruskimi i litewskimi). Niepewny pozostawał los ziem pod zaborem pruskim: Śląska Cieszyńskiego, Górnego Śląska, Pomorza wraz z Gdańskiem oraz Warmii i Mazur. Jedynie o losie Wielkopolski zadecydowali sami Polacy, wszczynając powstanie, które po dwóch miesiącach walk zakończyło się sukcesem.

\section{WOJNA POLSKO-UKRAIŃSKA O GALICJĘ WSCHODNIĄ}

Szczególnie bolesną sprawą dla nowego premiera była bratobójcza wojna polsko-ukraińska tocząca się o Galicję Wschodnią. Z chwilą upadku monarchii habsburskiej dwie główne nacje zamieszkujące byłą Galicję: Polacy i Ukraińcy rozpoczęli działania mające doprowadzić do powstania niepodległych państw. Przekształciły się one na początku listopada 1918 r. w otwarty konflikt zbrojny, który w kolejnych miesiącach powodował eskalację aktów przemocy. Głównym problemem polityków obu stron było rozgraniczenie spornych terytoriów, na których od kilku stuleci oba narody mieszkały w bezpośrednim sąsiedztwie, a nawet w tych samych rodzinach z powodu licznych małżeństw mieszanych. Dla strony polskiej miastem symbolem związanym z Polską od XIV stulecia był Lwów, o który toczono ze stroną ukraińską zacięte zmagania. Polacy dominowali liczebnie zarówno w tym mieście, jak i w innych ośrodkach miejskich, które jednak otaczały obszary wiejskie z przewagą ludności ukraińskiej. Ten sposób rozsiedlenia obu narodowości powodował trudności z wytyczeniem granicy podziału, która satysfakcjonowałaby obie strony. W skali całego spornego terytorium Galicji Wschodniej Ukraińcy stanowili ponad 60\% mieszkańców ${ }^{39}$.

${ }^{39}$ Według danych ostatniego austriackiego spisu ludności z 1910 r., językiem polskim w Galicji
Wschodniej posługiwało się ok. 28\% ludności, językiem ruskim (ukrainskim) zaś - 64\% ludności. 
Dla Paderewskiego, wychowanego w Kuryłówce na Podolu, w kontakcie z ukraińskim otoczeniem nie były to problemy nieznane. Od czasów jego dzieciństwa nastąpiło jednak szereg istotnych zmian w relacjach polsko-ukraińskich. Prosty powrót do granic historycznych dawnej Rzeczypospolitej nie był możliwy, z czego nowy premier zdawał sobie sprawę. Widział równocześnie konieczność porozumienia się ze stroną ukraińską, jednak nie za cenę wyrzeczenia się przez Polskę władzy nad Galicją Wschodnią. Optymalnym rozwiązaniem dla Paderewskiego byłoby przyznanie Polsce przez mocarstwa zachodnie spornego obszaru z nadaniem Ukraińcom autonomii na tym terytorium. W takim kierunku podejmował działania w kolejnych miesiącach swoich rządów.

Pierwsze sygnały o toczących się w Galicji walkach dotarły do Paderewskiego już w grudniu 1918 r. w czasie jego pobytu w Poznaniu. Ormiański arcybiskup lwowski, Józef Teodorowicz, wysłał wówczas dramatyczny apel o udzielenie wsparcia Polakom walczącym z Ukraińcami we Lwowie. 2 stycznia 1919 r. hierarcha ponownie skierował list do Paderewskiego prosząc o podjęcie działań u koalicji państw zachodnich, jak też o osobiste spotkanie w hotelu Bristol w Warszawie ${ }^{40}$. W kolejnych wystąpieniach Teodorowicz nie ustawał w zabiegach mających na celu rozwiązanie kwestii Galicji Wschodniej, w tym pośrednicząc w przyjęciu delegacji polskiej ze Lwowa przez Paderewskiego ${ }^{41}$. W połowie stycznia po utworzeniu rządu Paderewskiego państwa Ententy zaangażowały się w konflikt polsko-ukraiński, chcąc doprowadzić do przerwania działań zbrojnych i zawarcia przez strony rozejmu. Do Galicji skierowano przedstawicieli angielskiej i francuskiej misji wojskowej. Konieczność kompromisu stawała się sprawą pilną ze względu na zagrożenie na północno-wschodnim odcinku granicy ze strony bolszewickiej Rosji (która stanowiła groźbę także dla strony ukraińskiej). Próbę mediacji w konflikcie polsko-ukraińskim podjęli również hierarchowie katoliccy archidiecezji lwowskich obu obrządków - arcybiskup greckokatolicki Andrzej Szeptycki i arcybiskup rzymskokatolicki Józef Bilczewski ${ }^{42}$.

Podobne proporcje występowały przy kryterium wyznaniowym (ok. 22\% rzymscy katolicy, ok. 65\% grekokatolicy). Zob. T. PILaT, Podręcznik statystyczny Galicji, t. IX, cz. 1, Lwów 1913; I. WeINFELD, Ludność miejska Galicyi i jej skład wyznaniowy (1881-1910), „Wiadomości Statystyczne o stosunkach krajowych wydawane przez Krajowe Biuro Statystyczne" red. T. Pilat, t. XXIV, z. II, Lwów 1912; E. Romer, Geograficzno-statystyczny atlas Polski, Warszawa-Kraków 1916.

${ }^{40}$ AAN, AIJP, sygn. 748, s. 4-5; wersja opublikowana dokumentu w: Archiwum polityczne Ignacego Paderewskiego, t. II, s. 3.

${ }^{41}$ Tamże, sygn. 748, s. 6-7; listy opublikowane w: tamże, s. 9-10, 14-15.

${ }^{42}$ Efektem tego była m.in. wspólna odezwa metropolity Szeptyckiego i Bilczewskiego do dowództwa wojsk polskich i ukraińskich o wymianie jeńców z 15 grudnia 1918 r. Jej tekst w: Centralne Państwowe Archiwum Historyczne Ukrainy we Lwowie, zesp. 408, opys 4, sygn. 574, s. 11. Odezwa 
Propozycje rozejmowe złożone 28 stycznia 1919 r. przez Misję Wojskową, kierowaną przez francuskiego generała Josepha Bartholemy'ego, nie zostały przyjęte przez delegację Zachodnioukraińskiej Republiki Ludowej. Strona ukraińska odrzuciła również miesiąc później warunki rozjemcze proponowane przez tzw. Komisję Noulensa ${ }^{43}$.

Wątek granicy wschodniej został silnie zarysowany w przemówieniu Paderewskiego podczas 3. posiedzenia Sejmu Ustawodawczego w dniu 20 lutego 1919 r. Stanowiło ono krótkie podsumowanie działań rządu, także w zakresie polityki międzynarodowej. Premier podkreślał znaczenie obrony Lwowa i jego rolę jako kolebki polskiej kultury, jak też związki z Polską ziemi lwowskiej od czasów Kazimierza Wielkiego. Mówił na ten temat: „Jeżeli Warszawa była i jest sercem Polski, to przez te długie lata ucisku i niewoli Kraków i Lwów były jako tych płuc dwoje, którymi

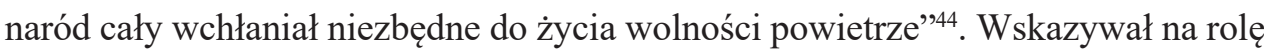
dalszych Kresów Wschodnich i wzywał do troski o los ponad 3 mln Polaków tam zamieszkałych. Równocześnie zaznaczał, że Polska nie powinna stać na drodze do odrębnego rozwoju innym narodowościom, lecz procesy te wspierać4 ${ }^{45}$. Odwoływał się przy tym do tradycji zgodnego współżycia różnych narodów w dawnej Rzeczypospolitej. 27 lutego 1919 r. w MSZ na polecenie Paderewskiego zebrała się Komisja do ustalenia granic Polski i uzgodnienia opracowanych przez nią map pokazujących przebieg tych granic. Obrady Komisji ujawniły rozbieżności nawet pomiędzy polskimi członkami tego gremium, co obrazowało skalę trudności, przed którymi stała polska delegacja w Paryżu, kierowana do kwietnia 1919 r. przez Romana Dmowskiego. 5 marca odbyło się w Warszawie 10. posiedzenie Sejmu Ustawodawczego, w czasie którego wystąpienie Paderewskiego zostało w całości poświęcone stanowi rokowań rozejmowych z Ukrainą. Premier wskazywał na głębokie podziały wśród sił politycznych ukraińskich i istnienie czterech różnych

opublikowana także w wydawnictwie źródłowym: Митрополит Андрей Шептицький. Життя і діяльність. Документи і матеріали 1899-1944, Львів 1998-1999, т. 2, кн. 2, s. 693.

Na temat działań mediacyjnych hierarchów zob. też: Nieznana korespondencja arcybiskupów metropolitów lwowskich Józefa Bilczewskiego z Andrzejem Szeptyckim w czasie wojny polsko-ukraińskiej 1918-1919, oprac. J. Wołczański, Lwów-Kraków 1997.

${ }^{43}$ Joseph Noulens (1864-1944) - francuski polityk i szef Komisji Rozjemczej, podobnie jak Bartholemy proponował rozgraniczenie Galicji Wschodniej, pozostawiając Lwów i naftowe Zagłębie Borysławsko-Drohobyckie po polskiej stronie.

${ }^{44}$ Sprawozdanie stenograficzne z 3. posiedzenia Sejmu Ustawodawczego z dnia 20 lutego 1919 r., http://dibra.umcs.lublin.pl/dlibra/publication?id=7520\&tab=3 [dostęp: 22.12.2019].

${ }^{45}$ Tamże. Fragment dotyczący Kresów Wschodnich w wersji opublikowanej sprawozdania w: Archiwum polityczne Ignacego Jana Paderewskiego, t. VI, s. 62. 
ośrodków władzy na Ukrainie ${ }^{46}$, co pogłębiało trudności negocjacyjne. W zaistniałej sytuacji Paderewski pokładał nadzieję w Komisji Międzysojuszniczej i jej pozytywnych dla Polski decyzjach.

Równocześnie premier próbował tworzyć politykę faktów dokonanych. 7 marca 1919 rozporządzeniem Rady Ministrów ustanowiony został Generalny Delegat Rządu dla byłego Królestwa Galicji i Lodomerii, który przejął kompetencje dawnego namiestnika Galicji.

Na temat forsowanej w Paryżu koncepcji polskiej granicy wschodniej wypowiadał się członek polskiej delegacji na konferencji pokojowej, Erazm Piltz, w memoriale przesłanym Paderewskiemu pod koniec marca 1919 r. ${ }^{47}$ Zwracał w nim przede wszystkim uwagę na zmianę stosunku aliantów, w tym Francji do kwestii narodowości walczących o uznanie ich jako suwerennych państw, powstałych na obszarze b. Imperium Rosyjskiego (Litwinów, Łotyszy, Estończyków i Ukraińców). Początkowo uważano ich za wrogów Ententy i w sposób negatywny lub obojętny traktowano ich postulaty. Obecnie, na co zwracał uwagę Piltz, uważa się w Paryżu ich przedstawicieli za równoprawnych partnerów i czyni daleko idące obietnice. W dalszej części memoriału wskazywał, że Ukraińcy będą w sporze o Galicję Wschodnią traktowani na równi z przedstawicielami Polski. W związku z tym zalecał stanowcze obstawanie przy Galicji jako integralnej części państwa polskiego, ale jednoczesne poczynienie dużych ustępstw na rzecz autonomii Ukraińców na tym obszarze.

Zwracał też uwagę na żądania strony litewskiej, która wprawdzie nie pretenduje do terytorium Litwy historycznej (wskrzeszenia dawnego Wielkiego Księstwa Litewskiego), ale też nie zadowala się obszarem Litwy etnograficznej, żądając m.in. włączenia Wilna do państwa litewskiego. Realnym zatem stanowiskiem według Piltza byłoby uznanie niepodległości Litwy w granicach etnograficznych i próba jak najściślejszego związania jej z Polską. Napływające w marcu 1919 r. informacje o stanie spraw polskich na obradach w Paryżu przekazywane przez Romana Dmowskiego i innych członków polskiej delegacji skłoniły premiera Paderewskiego do osobistego włączenia się w negocjacje pokojowe. Przybył on do francuskiej stolicy w dniu 5 kwietnia 1919 r. i przebywał w niej przez większość czasu aż do podpisania traktatu pokojowego w końcu czerwca. Jego zadaniem było wsparcie polskich działań na rzecz korzystnej dla Polski decyzji w sprawie Gali-

46 „Są właściwie cztery Ukrainy. Są zwolennicy p. Skoropadskiego, którego adiutantami podobno są Koczubej i Boratynskij, jest Ukraina Winniczenki, jest Ukraina Petlury i jest nasza, domorosła, dobrze znana Ukraina własnego chowu" (AAN, AIJP, sygn. 844, s. 10. Wersja opublikowana przemówienia w: Archiwum polityczne Ignacego Jana Paderewskiego, t. VI, s. 68).

${ }^{47}$ Tamże, sygn. 947, s. 17-23. Wersja opublikowana w: tamże, s. 81-83. 
cji Wschodniej, ale też innych ziem polskich. O nadziejach, jakie wiązano z jego obecnością na konferencji, świadczy wpis członka polskiej delegacji, Władysława Konopczyńskiego, który w swoim dzienniku pod datą 5 kwietnia notował: „Paderewski - ostatnią deską ratunku; jeżeli jego szczęście zawiedzie, to można spodziewać się najgorszych rzeczy"48. Dalszy bieg wydarzeń na konferencji pokazał, jak wiele wysiłku musiał włożyć Paderewski i inni członkowie polskiej delegacji $\mathrm{w}$ forsowanie polskiego stanowiska.

\section{ROLA PADEREWSKIEGO}

\section{W OBRADACH KONFERENCJI POKOJOWEJ W PARYŻU}

Na konferencji ścierały się interesy polityczne wielu państw. Na obrady przybyło ponad 30 delegacji, jednak głos decydujący miały mocarstwa tzw. Wielkiej Czwórki: Wielkiej Brytanii, Francji, Stanów Zjednoczonych i Włoch. Ich przywódcy nie byli zgodni w wielu kwestiach, o których mieli rozstrzygać, także w sprawie polskiej. Za najbardziej przychylnego Polsce i jej postulatom uważany był gospodarz konferencji, premier Francji George Clemenceau. Był skłonny pozytywnie potraktować postulaty włączenia Górnego Śląska i Gdańska wraz z Pomorzem do Polski, uważając Niemcy za największe zagrożenie zarówno dla interesów francuskich, jak i pokoju w Europie ${ }^{49}$. Odmienne stanowisko prezentował premier brytyjski Lloyd George, widzący w zbytnim osłabianiu Niemiec wzrost znaczenia Francji w Europie. To z nim delegacja polska na czele z Paderewskim toczyła zacięte debaty na temat roszczeń do wymienionych wyżej terytoriów. Najbliższe kontakty łączyły Paderewskiego z prezydentem Stanów Zjednoczonych, Woodrowem Wilsonem, którego wybitny artysta poznał podczas swoich amerykańskich tournée i występował z koncertami w Białym Domu. Znajomość ta przekształciła się w bliskie więzy przyjaźni pod koniec I wojny światowej, gdy Paderewski zyskał wpływ na polityczną działalność Wilsona i był dla prezydenta i jego otoczenia jednym z podstawowych źródeł informacji o historii Polski, jej wojennych doświadczeniach i prawach do suwerenności. Osobiste relacje obu polityków nie przekładały się jednak do końca na realne stanowisko USA wobec sprawy polskiej w czasie konferencji paryskiej. Idea samostanowienia narodów, także małych i przekonanie Wilsona o konieczności

\footnotetext{
${ }^{48}$ Władysław Konopczyński, Dziennik 1918-1921, cz. 1, oprac. P. Biliński, P. Plichta, WarszawaKraków 2016, s. 361.

${ }^{49}$ Paderewski również był oceniany jako polityk wybitnie profrancuski przez niemieckie ministerstwo spraw zagranicznych. Zob. K. JoNCA, Wojna polsko-sowiecka 1920 roku w dokumentach niemieckiej dyplomacji, Wrocław 2002, dokument 132, s. 354, dokument 134, s. 360.
} 
uwzględniania kryterium etnicznego w wytyczaniu granic w Europie nie zawsze szła w parze z interesami państwa polskiego.

Wizja odrodzonego państwa polskiego kreślona przez Paderewskiego związanego formalnie z obozem narodowym Romana Dmowskiego bliższa była koncepcji federacyjnej Józefa Piłsudskiego. Zauważali to wyraźnie uczestnicy konferencji pokojowej w Paryżu - Stanisław Kozicki, bliski współpracownik Dmowskiego, oraz Leon Wasilewski, delegat Piłsudskiego na konferencję. Pierwszy z nich, autor znanej pracy pt. Sprawa granic Polski na konferencji pokojowej w Paryżu 1919 r. (Warszawa 1921), pisał na ten temat: „Paderewski był zwolennikiem programu «federacji». Pragnął utworzenia państwa litewskiego i ukraińskiego i złączenia ich węzłami federacji z Polską. Podobne stanowisko zajmowała Delegacja specjalna od Naczelnika Państwa, która przybyła do Paryża pod przewodnictwem dr. Kazimierza Dłuskiego". Ocenę tę potwierdzał Leon Wasilewski w korespondencji z Paryża z kwietnia 1919 r.: „Paderewski stoi mocno na stanowisku federalistycznem i na tym punkcie w dalszym ciągu ściera się z Dmowskim. Na razie nie ma obawy, aby się dał zachwiać"50.

W walce o polskie granice na konferencji paryskiej wspierali Paderewskiego wybitni polscy uczeni, w tym historycy (Szymon Askenazy, Oskar Halecki, Władysław Konopczyński) oraz geografowie, z których największą rolę odegrał Eugeniusz Romer, znany już wówczas i ceniony jako naukowiec w kręgach międzynarodowych ${ }^{51}$. Znaczącą rolę w udowadnianiu praw Polski do spornych terytoriów miała przygotowana przez specjalistów dokumentacja kartograficzna ${ }^{52}$. Paderewski osobiście wykorzystywał mapy do obrazowego tłumaczenia zachodnim politykom skomplikowanych stosunków etnicznych, narodowościowych czy też innych kwestii związanych z sytuacją Polski i jej obywateli. Jednym z takich zabiegów dyplomatycznych było przygotowanie specjalnej mapy dla amerykańskiej opinii publicznej i jej przywódców, na której przedstawiono ogrom zniszczeń wojennych na ziemiach polskich, zestawiając go z terytorium Pensylwanii w Stanach Zjednoczonych ${ }^{53}$. O ogromnym wkładzie polskich uczonych i pomocy intelektualnej udzielonej polskim delegatom

${ }^{50}$ Archiwum Instytutu Józefa Piłsudskiego w Nowym Jorku, zesp. 2, Adiutantura Generalna Naczelnego Wodza, sygn. 105, s. 23. Na temat różnicy zdań między I.J. Paderewskim a R. Dmowskim pisał też W. Konopczyński, zob. Dziennik 1918-1921, cz. 1, s. 377.

${ }^{51}$ M. GóRnY, Karty na stół. Geografia i granice nowej Europy po I wojnie światowej, „Kwartalnik Historyczny”, 125(2018), z. 2, s. 164. Zob. też: E. RoMER, Pamiętnik paryski (1918-1919), oprac. A. Garlicki, R. Świętek, Wrocław 1989; W. KonopCZYŃski, Dziennik 1918-1921, cz. 1. Na temat składu delegacji polskiej zob. AAN, zesp. 322, Ministerstwo Spraw Zagranicznych, sygn. 92.

${ }^{52}$ Zbiór map, na których pracowała polska delegacja, w tym egzemplarze z odręcznymi dopiskami Paderewskiego, zachował się w kolekcji kartograficznej w Bibliotece Polskiej w Paryżu.

${ }^{53}$ Polish Music Center [dalej: PMC] w Los Angeles, Stojowski Collection, Mapa pt. Poland Eastern Theater of War. 
na konferencję: Paderewskiemu i Dmowskiemu świadczy zachowana dokumentacja Biura Prac Kongresowych ${ }^{54}$, obejmująca ponad 250 tomów opracowań historycznych, analiz ekonomicznych, opracowań kartograficznych ${ }^{55}$. Wszystkie one miały służyć udowodnieniu praw Polski do terytoriów spornych, o które polscy delegaci toczyli dyplomatyczne zmagania w Paryżu.

Wiele wysiłku kosztowała Paderewskiego walka o korzystne dla Polski rozwiązania w kwestii ziem zaboru pruskiego, a zwłaszcza Górnego Śląska z jego uprzemysłowionym regionem. Polski premier znajdował się w trudnej sytuacji nie tylko z powodu toczącej się na konferencji gry dyplomatycznej mocarstw i oporu Wielkiej Brytanii, obawiającej się zbytniego osłabienia Niemiec. Działania strony niemieckiej, w tym liczne incydenty wrogie Polakom na Śląsku groziły wybuchem konfliktu zbrojnego. $\mathrm{Z}$ tego powodu Paderewski zabiegał o obsadzenie terytorium Śląska wojskami amerykańskimi, które jako siły międzynarodowe mogłyby kontrolować sytuację i wywierać uspokajający wpływ na ludność prowokowaną nieustannie do powstania. Taki argument zawarł w liście skierowanym 18 lipca 1919 r. do Roberta Lansinga, sekretarza stanu w administracji prezydenta Wilsona ${ }^{56}$. Gdy ta opcja okazała się niemożliwa do realizacji, Paderewski z analogiczną prośbą wystąpił do państw Ententy - Francji i Wielkiej Brytanii. Szczególnie napięta atmosfera panowała w ostatnich dniach przed podpisaniem traktatu pokojowego. Paderewski wysyłał wówczas alarmujące telegramy z Paryża do polskich władz o utrzymanie za wszelką cenę stabilnej sytuacji na Śląsku. W telegramie z 26 czerwcu 1919 r. premier polecał marszałkowi Trąmpczyńskiemu poinformowanie Wojciecha Korfantego oraz polskich posłów zaboru pruskiego o konieczności zapobieżenia wybuchowi powstania na Górnym Śląsku. W wiadomości tej pisał: „Proszę na wszystko o użycie wszelkiego wpływu, wszelkich środków dla powstrzymania naszego ludu od szaleństw. Jakikolwiek nierozważny krok może stać się przyczyną zguby. Na drodze pokojowej osiągniemy najwięcej”'57.

${ }^{54}$ Organizacja powstała w listopadzie 1918 r., podległa Ministerstwu Spraw Zagranicznych. Jej celem było świadczenie pomocy naukowej i przygotowanie materiałów na konferencję pokojową w Paryżu. Biuro w Warszawie miało swoje oddziały w Paryżu, Krakowie i Poznaniu. Oddział paryski zlikwidowano z dniem 1 lipca 1919 r. po zakończeniu obrad konferencji pokojowej, warszawska centrala $\mathrm{z}$ kolei została włączona jako wydział do MSZ.

${ }^{55}$ AAN, zesp. 515, Biuro Prac Kongresowych, seria nr 4, Referaty, memoriały przygotowane dla Delegacji Polskiej na Konferencję Pokojową 1919-1920, sygn. 45-303.

${ }^{56}$ AAN, AIJP, sygn. 906, s. 36. Dokument opublikowany w: Archiwum polityczne Ignacego Paderewskiego, t. II, s. 281-282.

57 AAN, AIJP, sygn. 905, s. 45. Telegram opublikowany w: Archiwum polityczne Ignacego Paderewskiego, t. II, s. 219-220 oraz w: Sprawy polskie na konferencji pokojowej w Paryżu w 1919 r. Dokumenty i materiaty, t. II, s. 76. 
Po kilku miesiącach dyplomatycznych zmagań w dniu 28 czerwca 1919 r. doszło do podpisania traktatu wersalskiego kończącego I wojnę światową. Ze strony polskiej podpisy złożyli: Ignacy Jan Paderewski i Roman Dmowski jako polscy delegaci na konferencję. Zawarty traktat nie rozstrzygnął przynależności do Polski ani ziem zaboru pruskiego, ani Galicji Wschodniej. W odniesieniu do Górnego Śląska, Warmii i Mazur o losach tych ziem miały zdecydować plebiscyty. W przypadku Galicji Wschodniej tuż przed podpisaniem traktatu, w dniu 25 czerwca 1919 r. konferencja pokojowa akceptowała tymczasową administrację Polski na spornym terytorium. W tym czasie strona polska angażując nowe siły wojskowe (armię gen. Józefa Hallera ${ }^{58}$ ) rozpoczęła od maja ofensywę, która doprowadziła do wypchnięcia oddziałów Ukraińskiej Halickiej Armii za rzekę Zbrucz w lipcu 1919 r. O korzystnym werdykcie dla Polski ze strony mocarstw, pomimo akcji militarnej wobec Ukraińców, zdecydowały m.in. działania Paderewskiego, który udzielał prezydentowi Wilsonowi i Radzie Najwyższej obszernych wyjaśnień. Wskazywał w nich na demoralizację armii ukraińskiej oraz szerzenie się w niej wpływów bolszewickich, jak też na brak jednego ośrodka władzy politycznej po stronie ukraińskiej ${ }^{59}$. Po podpisaniu traktatu wersalskiego, który nie rozstrzygał kwestii przynależności państwowej spornych terytoriów, Paderewski nadal toczył w Paryżu walkę dyplomatyczną o ostateczne włączenie Galicji Wschodniej do Polski. We wrześniu 1919 r. szef Polskiej Misji Wojskowej w Paryżu, gen. Tadeusz Rozwadowski raportował na ten temat do Naczelnego Dowództwa w Warszawie:

\begin{abstract}
Sprawa Galicji Wschodniej powróciła na stół konferencji forsowana znowu przez Anglików. Wczoraj uzasadniał Pan Prezydent ministrów Paderewski przed Radą Pięciu nasze stanowisko i zastrzegał się przeciw wszelkiemu prowizorjum, jako uniemożliwiającemu przeprowadzenie zupełnego uspokojenia oraz możliwego zagospodarowania tego tak wyniszczonego kraju obecnie. Dzisiaj obrabiali delegaci angielscy naszego premjera bardzo długo, lecz zupełnie bezskutecznie $[\ldots]^{60}$.
\end{abstract}

${ }^{58}$ Potocznie zwana Błękitną Armią od koloru mundurów, sformowana we Francji na podstawie dekretu prezydenta Raymonda Poincaré z 4 czerwca 1917 r. Jej powstanie było skutkiem usilnych zabiegów Ignacego Paderewskiego, który pierwotnie starał się o utworzenie polskich sił zbrojnych stanowiących część armii amerykańskiej. W skład armii Hallera weszło ponad 27 tys. ochotników polskiego pochodzenia ze Stanów Zjednoczonych i Kanady. W 1919 r. osiągnęła ona stan 70 tys. żołnierzy, którzy rekrutowali się w znacznej części z polskich jeńców wojennych w wielu krajach Europy i poza nią. Zob. D. Radziwilıowicz, Btękitna Armia. W 80. rocznicę utworzenia, Warszawa 1997; J. HaLLER, Pamiętniki z wyborem dokumentów i zdjęć, Londyn 1964 (wyd. I), Łomianki 2014 (wyd. II).

${ }^{59}$ P.P. ŻURAwSKI Vel GraJewsKi, Sprawa ukraińska na konferencji pokojowej w Paryżu w roku 1919, Warszawa 2017, s. 50, 56-57.

${ }^{60}$ Archiwum Instytutu Józefa Piłsudskiego w Nowym Jorku, zesp. nr 2, Adiutantura Generalna Naczelnego Wodza, sygn. 105, s. 163. 
Szczegółowe sprawozdanie ze swoich działań w Paryżu przedstawił Paderewski osobiście na posiedzeniu Komisji Zagranicznej w Warszawie w dniu 29 października 1919 r. W relacji tej składanej przedstawicielom wszystkich sił politycznych podkreślił, że polskie żądania przyłączenia Galicji popierała strona francuska, reprezentowana przez marszałka Ferdynanda Focha (jako zastępcy prezydenta Wilsona), przeciwny był jednak premier brytyjski Lloyd George ${ }^{61}$. W rezultacie kwestia ta pozostawała w zawieszeniu do końca sprawowania urzędu premiera przez Paderewskiego.

Stan tymczasowości na terenie Galicji trwał przez kolejne lata aż do $1923 \mathrm{r}$. Państwa Ententy i organy przez nie wyłonione (Rada Ambasadorów oraz Rada Ligi Narodów) do tego czasu uznawały Galicję Wschodnią za terytorium sporne, nienależące do państwa polskiego, nad którym kontrolę sprawują państwa Ententy na mocy ich traktatu pokojowego z Austrią. Państwa Europy Zachodniej w tym okresie liczyły na zwycięstwo białej Rosji i porozumienie się z nią, co wprowadziłoby nową sytuację nie tylko w odniesieniu do Galicji Wschodniej, ale całej wschodniej granicy Polski i bytu nowo odrodzonego państwa. Zdając sobie sprawę z tego zagrożenia, Józef Piłsudski nie angażował się zbrojnie w działania zachodnich aliantów wspierających armię Denikina, gdyż za równie szkodliwe dla Polski uznawał zwycięstwo bolszewików, jak i ich politycznych oponentów ${ }^{62}$. Równocześnie władze polskie prowadziły na terenie Galicji Wschodniej politykę faktów dokonanych, starając się integrować ją z państwem polskim. Temu służyła m.in. ustawa o samorządzie wojewódzkim z września 1922, w której tytule oraz treści określono szczególny charakter terytorium Galicji Wschodniej w ramach państwa polskiego. Po zwycięstwie w Rosji władzy bolszewickiej alianci zmienili swoją politykę. W nowej sytuacji, 15 marca 1923 r. Rada Ambasadorów uznała władzę Polski w Galicji Wschodniej oraz zobowiązała stronę polską do wprowadzenia autonomii na wymienionym terytorium. Po tej decyzji rozwiązał się rząd Zachodnioukraińskiej Republiki Ludowej urzędujący na emigracji w Wiedniu.

\section{3. ŚLĄSK CIESZYŃSKI}

Wbrew intencjom i wysiłkom Paderewskiego rozstrzygnięta została sprawa przynależności państwowej Śląska Cieszyńskiego ${ }^{63}$. Inicjatywę na tym terenie przejęła

${ }^{61}$ Tamże, s. 246.

${ }^{62}$ A. ZAmoYski, Warszawa 1920. Nieudany podbój Europy. Klęska Lenina, Kraków 2009, s. 30. Do uderzenia na Rosję i wsparcia Białych namawiał Piłsudskiego zwłaszcza brytyjski minister wojny, Winston Churchill.

${ }^{63}$ Instytut Polski i Muzeum im. gen. Sikorskiego w Londynie, zesp. A.11, Ministerstwo Spraw Zagranicznych, nr podzespołu 49/Cz, sygn. 1, Śląsk Cieszyński - zbiór tekstów informacyjnych 
strona czeska, zajmując zbrojnie ten obszar 23 stycznia 1919 r., w kilka dni po rozpoczęciu obrad przez konferencję pokojową w Paryżu. Aktem tym wojska czeskie, działające na polecenie premiera Karla Kramářa i prezydenta Tomáša Masaryka, złamały postanowienia umowy polsko-czeskiej z 5 listopada 1918 r., która dokonywała rozgraniczenia spornego terytorium według kryterium etnicznego. Celem rządu czeskiego było włączenie do Czechosłowacji całego Śląska Cieszyńskiego, do czego nie doszło wskutek zatrzymania ofensywy czeskiej i włączenia się do konfliktu Ententy. Pod naciskiem mocarstw zachodnich nastąpiło zawieszenie broni oraz podjęto trudne i długotrwałe negocjacje. 25 lutego 1919 r. udało się stronie polskiej zająć wschodnią część miasta Cieszyn. Pozostałe tereny zajęte przez wojska czechosłowackie pozostały poza polską kontrolą.

Dzięki działaniom dyplomatycznym Paderewskiego wiosną 1919 r. nastąpiła zmiana niekorzystnego dla Polski stanowiska członków Rady Najwyższej. Zablokowano wówczas decyzję o przyznaniu Czechosłowacji całych powiatów frysztackiego i cieszyńskiego, a Polsce jedynie powiatu bielskiego. W lipcu 1919 r. obie strony przeprowadziły nieudane rozmowy, w czasie których strona polska zaproponowała plebiscyt na terenie powiatów cieszyńskiego i frysztackiego ${ }^{64}$. Władze Czechosłowacji zgodziły się na takie rozstrzygnięcie dopiero w październiku 1919 r. w Paryżu pod naciskiem przedstawicieli Ententy. Przygotowanie do plebiscytu prowadzono od stycznia do marca 1920 r. Miał się on odbyć pod kontrolą przedstawicieli mocarstw. Ostatecznie jednak do plebiscytu nie doszło wskutek pogorszenia się sytuacji międzynarodowej Polski latem 1920 r. w związku z inwazją bolszewicką. Czeski minister spraw zagranicznych Edvard Beneš na konferencji w Spa (11 lipca) zdołał przeforsować swoją propozycję, według której o podziale Śląska Cieszyńskiego miały zdecydować mocarstwa bez przeprowadzania plebiscytu. Reprezentujący władze polskie premier Władysław Grabski ugiął się pod presją i zaakceptował postulat Beneša, licząc na pomoc mocarstw w wojnie Polski z armią bolszewicką, zagrażającą Warszawie ${ }^{65}$. Strona czechosłowacka z kolei miała zachować neutralność w toczonej przez Polskę wojnie i przepuszczać transporty ze sprzętem dla armii polskiej. Ze zobowiązania tego władze Czechosłowacji się nie wywiązały. 28 lipca 1920 r. Rada Ambasadorów podjęła decyzję o podziale Śląska Cieszyńskiego, przyznając Polsce 44\% spornego terytorium, a 66\% oddano

i dokumentacyjnych ułożony na podstawie materiałów archiwalnych Ambasady RP w Londynie, 1918-1921.

${ }^{64} \mathrm{Na}$ temat działań polskich w sprawie rozszerzenia granic plebiscytu: AAN, AIJP, sygn. 927, s. 36-40, 41.

${ }^{65}$ AAN, AIJP, sygn. 789, s. 12-13, List Erazma Piltza do Paderewskiego ze Spa w Belgii, 12 lipca 1920 r.; tamże, sygn. 928, s. 5-6, Notatka posła Piltza w sprawie cieszyńskiej z 11 lipca 1920 r. Por. też: N. DAVIES, Orzeł biały, gwiazda czerwona. Wojna polsko-bolszewicka 1919-1920, Kraków 1997, s. 169. 
Czechosłowacji, w tym tereny zamieszkałe w większości przez ludność polską. Obszar ten określany później jako tzw. Zaolzie, obejmował część powiatów frydeckiego, frysztackiego i cieszyńskiego oraz połowę miasta Cieszyna.

Decyzja mocarstw wywołała burzliwą debatę w środowisku polityków polskich. W czasie sejmowego wystąpienia we wrześniu 1920 r. następca Grabskiego na stanowisku premiera, Wincenty Witos, tłumaczył trudną sytuację poprzedników oraz krytykował decyzję Rady Ambasadorów krzywdzącą dla Polski, uważając, że wykopie ona przepaść między obu narodami ${ }^{66}$. Opinia ta znalazła swoje potwierdzenie w latach późniejszych, gdy na Zaolziu dochodziło do zadrażnień i sporów o charakterze narodowościowym ${ }^{67}$. Zajęcie tego obszaru przez Polskę w 1938 r. spowodowało dalsze pogorszenie relacji z Czechosłowacją.

\section{POWSTANIA ŚLĄSKIE}

Ogromne znaczenie strategiczne dla odrodzonego państwa polskiego miała kwestia przynależności do niego Górnego Śląska, nierozwiązana w paryskim traktacie pokojowym. Narastające napięcie wokół przyszłości tego terytorium doprowadziło do próby zbrojnego rozstrzygnięcia i wybuchu pierwszego powstania śląskiego w nocy z 16 na 17 sierpnia 1919 r. Decyzja ta została podjęta wbrew woli i stanowisku rządu polskiego kierowanego przez Paderewskiego, który uważał, że zgodnie z wcześniejszymi ustaleniami, decyzje w tej sprawie powinny podjąć mocarstwa

${ }^{66}$ W mowie sejmowej z 24 września 1920 r. Witos stwierdzał: „W międzyczasie spotkał naród polski cios, który silnie zaważył i zaważyć musiał na kształtowaniu się naszego stosunku do republiki czechosłowackiej. Wyrokiem Rady Ambasadorów, na której sąd zgodził się rząd poprzedni, porzucając myśl plebiscytu, bo pragnął jak najprędzej położyć kres anormalnym stosunkom na poddanych plebiscytowi terenach, przyznany został Czechom szmat rdzennie polskiej ziemi, mającej bardzo znaczną większość polską. Przyznane zostały Czechom nawet te okręgi, do których Czesi nie powinni nigdy rościć pretensji. Naród nasz i Rząd nigdy nie pożądał cudzych ziem, tembardziej też nie może zrozumieć krzywdy, jaką mu wyrokiem w sprawie Śląska Cieszyńskiego i Spiszu wyrządzono. Wyrok ten wykopał przepaść między oboma narodami, które splot interesów politycznych i gospodarczych wiąże ze sobą". Sprawozdanie stenograficzne ze 167. posiedzenia Sejmu Ustawodawczego 24 września 1920, kol. CLXVII/16, dostępne na stronie internetowej biblioteki cyfrowej UMCS: http://dlibra.umcs.lublin.pl/dlibra/publication?id=8897\&tab=3 [dostęp: 22.12.2019].

${ }^{67}$ Szerzej na temat stosunków politycznych zob.: M. WANATOwICz, Historia społeczno-polityczna Górnego Śląska i Śląska Cieszyńskiego w latach 1918-1945, Katowice 1994; Ślask Cieszyński od Wiosny Ludów do I wojny światowej w latach 1848-1918, red. I. Panic, K. Nowak, Cieszyn 2013; Śląsk Cieszyński w latach 1918-1945, red. K. Nowak, Cieszyn 2015; G. WnĘTRZAK, Stosunki polityczne i narodowościowe na pograniczu Ślaska Cieszyńskiego i Galicji zachodniej w latach 1897-1920, Toruń 2014. 
sojusznicze. Z kolei społeczeństwo domagało się od premiera udzielenia pomocy walczącym powstańcom. W Warszawie 29 sierpnia 1919 r. zorganizowano wiec na placu Teatralnym, który zgromadził niemal 100000 osób. W przyjętej rezolucji wzywano rząd polski do zdecydowanych kroków w celu powstrzymania aktów przemocy popełnianych przez Niemców oraz „najszybszego przyłączenia prastarej dzielnicy polskiej do Rzeczypospolitej" ${ }^{68}$. Podobne apele napływały z innych miast w Polsce. Powstanie, które objęło kilka śląskich powiatów (katowicki, lubliniecki, pszczyński, rybnicki, tarnogórski oraz część raciborskiego), upadło po kilku dniach walk 24 sierpnia. Skuteczna interwencja wojska polskiego była niemożliwa ze względu na zaangażowanie Polski w obronę wschodniej granicy przed armią Rosji sowieckiej. Rząd Paderewskiego w kolejnych dniach i miesiącach podejmował działania dla uspokojenia sytuacji na Śląsku i obsadzenia tego terytorium oddziałami alianckimi ${ }^{69}$.

O przyszłości dzielnicy śląskiej nie rozstrzygnęło także drugie powstanie, choć jego inicjatorzy odnieśli szereg sukcesów. Wybuchło ono w momencie zaangażowania rządu Władysława Grabskiego w odparcie ofensywy bolszewickiej spod Warszawy (rozpoczęło się w nocy z 19/20 sierpnia i trwało do 25 sierpnia). Powstanie doprowadziło do usunięcia $z$ terenów plebiscytowych policji niemieckiej oraz powstrzymało okresowo akty przemocy wobec ludności polskiej.

Decydujące znaczenie miało dopiero trzecie powstanie śląskie ${ }^{70}$. Rozpoczęło się ono w nocy z 2 na 3 maja $1921 \mathrm{r}$. na znak protestu przeciwko przegranemu przez stronę polską plebiscytowi ${ }^{71}$ oraz niekorzystnej propozycji podziału Śląska przedstawionej przez Międzysojuszniczą Komisję Rządzącą i Plebiscytową ${ }^{72}$. Ignacy Paderewski przebywał w tym czasie w Stanach Zjednoczonych, przygotowując się do kolejnego tournée, które miało być pierwszym jego występem artystycznym

${ }^{68}$ AAN, AIJP, sygn. 906, s. 11 i następne.

${ }^{69}$ AAN, AIJP, sygn. 906, s. 58, 62-64, 68-69.

${ }^{70}$ Akta trzech powstań śląskich, uratowane z Warszawy w 1939 r. jako fragment tzw. archiwum belwederskiego wywieziono do Stanów Zjednoczonych. W 1943 r. po utworzeniu w Nowym Jorku Instytutu Józefa Piłsudskiego stały się one częścią jego zbiorów. Są one przechowywane w tej instytucji do dnia dzisiejszego i dostępne online na stronie: http://www.pilsudski.org/powstania/ index.php. Ich uzupełnieniem są materiały zachowane w Archiwum Państwowym w Katowicach. Zob. Zespoty akt do dziejów powstań śląskich i plebiscytu na Górnym Śląsku z lat 1918-1950 w zasobie Archiwum Państwowego w Katowicach, oprac. E. Długajczyk, P. Greiner, S. Krupa, Katowice 2011. Dokumenty w wersji zdigitalizowanej są udostępniane na stronie archiwum: https://www. katowice.ap.gov.pl/art,311,archiwalia-z-okresu-plebiscytu-i-powstan-slaskich-z-lat-1918-1922 oraz w ogólnopolskim serwisie archiwalnym: www.szukajwarchiwach.gov.pl.

${ }^{71}$ W plebiscycie wzięło udział 1190637 osób, z czego za Niemcami głosowało 707393 osób (59,4\%), a za Polską 479365 (40,3\%).

72 Proponowała ona przyznanie Niemcom niemal 3/4 terytorium plebiscytowego. 
po pięciu latach zajmowania się sprawami politycznymi. Nadal jednak interesował się wydarzeniami w kraju, o czym świadczy jego reakcja na wieść o kolejnym powstaniu na Śląsku. Swoje odczucia zawarł w liście wysłanym ze swojego kalifornijskiego rancho w Paso Robles do Roberta Lansinga. Pisał w nim, że wybuch III powstania śląskiego nie był do końca spodziewany i stanowił dla niego i jego żony prawdziwy szok $^{73}$. O rozwoju sytuacji w kraju i stanie sprawy Śląska na arenie międzynarodowej informował Paderewskiego jego sekretarz, Sylwin Strakacz. 16 sierpnia 1921 r. donosił, że zmiana rządu we Francji (upadek gabinetu Aristide Brianda) spowoduje klęskę sprawy polskiej. W alarmującym tonie informował: „Jak się wyraża Korfanty, nowy rozbiór Polski jest już tylko kwestią czasu"74. Strakacz ubolewał, że po rezygnacji Paderewskiego z funkcji premiera Polska przegrywa na arenie międzynarodowej, także w kwestii Galicji Wschodniej ${ }^{75}$. Do sprawy Śląska powrócił Paderewski w poufnej korespondencji z Józefem Orłowskim, któremu we wrześniu 1921 r. przesłał wskazówki dotyczące kierunku działań redakcji „Rzeczypospolitej” po wybuchu III powstania śląskiego. Postulował wówczas, aby wyjaśniać społeczeństwu, że rząd polski nie zrobił wszystkiego dla sprawy przyłączenia całego Śląska do Polski, gdyż ,posłuszny najwyższym rozkazom lekkomyślnie wysunął sprawę wileńską przed śląską”. Zwracał uwagę, że to rząd ponosił odpowiedzialność za utratę Śląska, a nie tylko nieprzychylna postawa Wielkiej Brytanii („Anglia przecież chciała wejść z nami w bliższe stosunki, ofiarowała nam pomoc moralną i materialną, aleśmy ją odrzucili” ${ }^{76}$.

Sukcesy wojskowe odniesione przez powstańców śląskich po krwawych walkach doprowadziły do rozejmu, a następnie skłoniły Międzysojuszniczą Komisję Rządzącą i Plebiscytową do wysunięcia w październiku 1921 r. nowej, korzystniejszej dla Polski propozycji podziału Górnego Śląska ${ }^{77}$. Uzyskała ona o niemal 1/3 większe terytorium $\mathrm{w}$ stosunku do poprzednio proponowanego oraz obszar uprzemysłowiony, na którym funkcjonowało 50\% przemysłu hutniczego i 76\% kopalń węgla. Decyzja ta miała ogromne znaczenie dla dalszego rozwoju gospodarczego II Rzeczypospolitej. Przez kolejne ponad pół roku - do 4 lipca 1922 r. trwało przejmowanie przypadłych

73 "The Upper Silesian events, though not wholly unexpected, gave us a real shock" (AAN, AIJP, sygn. 1263, List Paderewskiego do Roberta Lansinga z 16 czerwca 1921 r., s. 14. Wersja drukowana listu: Archiwum polityczne Ignacego Paderewskiego, t. III, s. 10-11).

${ }^{74}$ AAN, AIJP, sygn. 1508, s. 24-27. Dokument opublikowany w: Archiwum polityczne Ignacego Paderewskiego, t. III, s. 24-25.

75 Tamże.

${ }^{76}$ AAN, AIJP, sygn. 1364, s. 62-63. Telegram zachował się mimo dyspozycji Paderewskiego dopisanej na jego końcu: „Proszę telegram spalić”.

77 AAN, zesp. 322, MSZ, sygn. 207, Górny Śląsk. Decyzje Rady Najwyższej, konferencji Ambasadorów i Rady Ligi Narodów w sprawie podziału Górnego Śląska. 
Polsce terytoriów. Oficjalne przekazanie władzy przez aliantów w ręce polskie miało miejsce 14 lipca 1922 r. 16 lipca podpisano w Katowicach dokument upamiętniający przejęcie wschodniej części Górnego Śląska przez Rzeczpospolitą Polską ${ }^{78}$.

\section{GDAŃSK POLSKIM OKNEM NA ŚWIAT}

Ważną rolę odegrał Paderewski w sprawie ustalenia przynależności państwowej Gdańska. Swoje stanowisko w tej sprawie wypowiadał wielokrotnie na forach międzynarodowych, przede wszystkim podczas obrad konferencji w Paryżu. Tuż po przybyciu do francuskiej stolicy, 6 kwietnia 1919 r. Paderewski udzielił wywiadu agencji Havasa ${ }^{79}$, w którym podkreślił, że zasadnicze polskie żądania dotyczą przyłączenia do Polski Gdańska wraz z wybrzeżem, jak też Śląska Cieszyńskiego i Lwowa. Uzasadniając wagę portu gdańskiego dla Polski, premier odwoływał się do argumentów politycznych, gospodarczych, ale też historii miasta i jego związków z Rzeczpospolitą ${ }^{80}$. Działania premiera wspierał Szymon Askenazy, wybitny historyk, którego głośna w Europie książka pt. Gdańsk a Polska (Warszawa 1919) była wykorzystywana do uzasadnienia historycznych praw Polski do tego miasta. Paderewski nie zdołał w ciągu kilku miesięcy przeforsować na arenie międzynarodowej swojego planu, głównie wobec zdecydowanego oporu brytyjskiego premiera Lloyda George'a. Gdańsk został ostatecznie Wolnym Miastem. Polski premier walczył o przyznanie Gdańska Polsce najpierw w trakcie konferencji pokojowej, a następnie jako prezes specjalnie w tym celu powołanej Komisji ds. Gdańska. Przez wiele miesięcy negocjował tekst dokumentu ustalający status miasta. W tej kwestii, podobnie jak przy Galicji Wschodniej, napotkał na opór Anglii, która dążyła do umiędzynarodowienia portu gdańskiego. Na przebieg pertraktacji prowa-

${ }^{78}$ Dokument ten zachował się w zasobie Archiwum Państwowego w Katowicach, zesp. 27, Urząd Wojewódzki Śląski, sygn. 19. W dniu 28 września 2018 r. został on wpisany na Listę Krajową Programu UNESCO „Pamięć Świata” jako jedno z najważniejszych świadectw odzyskiwania przez Polskę niepodległości. Opublikowano go w: Pamięć Polski. Dokumenty Niepodległej. Wystawa III edycji Polskiej Listy Krajowej Programu UNESCO Pamięć Świata. Wydanie specjalne z okazji XX Powszechnego Zjazdu Historyków Polskich w Lublinie, 18-20 września 2019 r., Warszawa 2019, s. 34-35. Zob. też: E. MatuSZEK, Akt pamiątkowy objęcia Górnego Ślaska przez Rząd Rzeczypospolitej Polskiej. Dzieje jednego dokumentu, Katowice 2019.

${ }^{79}$ Pierwsza na świecie nowoczesna agencja informacyjna utworzona w 1835 r. w Paryżu. Nazwę wzięła od założyciela Charles'a Louisa Havasa. Zatrudniała Paula Juliusa Reutera i Bernharda Wolffa, którzy założyli później własne agencje w Londynie i Berlinie. Agencja Havas działała do 1940 r., w 1944 r. w jej miejsce utworzono Agence France Presse działającą do dnia dzisiejszego.

${ }^{80}$ Ignacy Jan Paderewski. Myśli o Polsce i Polonii, s. 190. 
dzonych przez Paderewskiego niekorzystny wpływ miały zobowiązania podjęte przez premiera Grabskiego na konferencji w Spa w lipcu 1920 r. Grabski zobowiązał się wówczas do uznania treści umowy polsko-gdańskiej proponowanej przez mocarstwa, w tym zawierającej niekorzystne dla Polski zapisy, wprowadzone pod naciskiem brytyjskiego premiera Lloyda George. Paderewski starał się pozyskać dla stanowiska Polski stronę francuską, zwracając uwagę, że propozycje angielskie odbiegają od zasad przyjętych w traktacie wersalskim i zagrażają polskim interesom nad Bałtykiem. Chodziło przede wszystkim o przyznane wcześniej Polsce prawo do administracji i kontroli Wisły oraz portu w Gdańsku. W październiku 1920 r. doszło do odrzucenia przez Paderewskiego treści konwencji polsko-gdańskiej, przedstawionej mu do podpisu. Rząd polski wysłał do Rady Ambasadorów uzasadnienie tego kroku strony polskiej. Powstał nowy projekt, a wobec przedłużających się negocjacji Anglicy zagrozili wyjściem z koalicji. Paderewski poinformował o tym Ministerstwo Spraw Zagranicznych w telegramie z 28 października 1919 r. Wobec niemożliwości uzyskania dalszych ustępstw od Anglików rząd polski 3 listopada upoważnił Paderewskiego do podpisania konwencji polsko-gdańskiej. Doszło do tego w Paryżu 9 listopada 1920 r. ${ }^{81}$ Decyzja o przyznaniu Polsce stałego mandatu obrony Wolnego Miasta Gdańska została przekazana Lidze Narodów z przychylną rekomendacją wielkich mocarstw ${ }^{82}$.

\section{PADEREWSKI JAKO DELEGAT POLSKI ZA GRANICĄ (1920-1921)}

Ignacy Paderewski po dymisji z funkcji prezydenta Rady Ministrów podpisanej przez Piłsudskiego 9 grudnia 1919 r. pozostał w Warszawie do początku 1920 r. W lutym opuścił Polskę udając się z żoną Heleną do swojej szwajcarskiej posiadłości Riond Bosson. Zagrożenie ze strony bolszewickiej Rosji latem 1920 r. skłoniło władze polskie do ponownego zwrócenia się do niego o pomoc. Po informacjach napływających od Piltza Paderewski wysłał krótki telegram do swojego następcy, Władysława Grabskiego, o gotowości oddania się do dyspozycji rządu polskiego w związku z sytuacją wojenną i dyplomatyczną Polski ${ }^{83} .18$ lipca 1920 r. premier Grabski poprosił Paderewskiego o przyjęcie nominacji na delegata Polski na Kon-

\footnotetext{
${ }^{81}$ Archiwum Państwowe w Gdańsku, zesp. 259, Komisarz Generalny Rzeczypospolitej w Gdańsku, seria 1, sygn. 8, Komisja w sprawie Gdańska pod przewodnictwem prezesa Ignacego Paderewskiego, Paryż $1920 \mathrm{r}$.

${ }^{82}$ Szczegółowo na temat przebiegu negocjacji: Archiwum Instytutu Józefa Piłsudskiego w Nowym Jorku, zesp. nr 3, sygn. 2, s. 447-556.

${ }^{83}$ AAN, AIJP, sygn. 789, s. 23.
} 
ferencję Ambasadorów i w Lidze Narodów ${ }^{84}$. Pod aktem tym podpisali się naczelnik państwa Józef Piłsudski i minister spraw zagranicznych Eustachy Sapieha ${ }^{85}$. Paderewski objąwszy wymienioną funkcję, podjął próbę odrzucenia postanowień konferencji w Spa, niekorzystnych dla Polski w sprawie Śląska Cieszyńskiego, Spisza i Orawy oraz Gdańska. Uruchomił też swoje kontakty w Stanach Zjednoczonych, aby zjednać dla tej kwestii prezydenta USA, Wilsona. Przewodniczący Wydziału Narodowego Polskiego, Jan Smulski 22 lipca 1920 r. zwrócił się do Paderewskiego o poparcie zabiegów podjętych przez przywódców Polonii amerykańskiej w celu moralnej interwencji na rzecz Polski ${ }^{86}$. W tym samym czasie Paderewski wystąpił z prośbą do swojego dawnego znajomego i przyjaciela, Edwarda House'a o przyjęcie i wysłuchanie delegacji Polaków ze Śląska Cieszyńskiego. Wysiłki te nie przyniosły większych rezultatów. Jak pisał Paderewski do Eustachego Sapiehy, podjęte one zostały zbyt późno, a wobec wcześniejszej zgody rządu polskiego na podyktowane warunki ,wyklucza możliwość jakiejkolwiek obrony, czyni wszelkie zabiegi bezowocnymi. Staram się już tylko usilnie o złagodzenie wyroku, który został postanowiony, zanim do rozprawy przyszło, i który nas wydziedzicza ze wszystkich bogactw Cieszyńskiego Śląska" ${ }^{\text {"87 }}$. Ostatecznie Paderewski musiał akceptować przyjęte przez Grabskiego w Spa warunki, choć złożył protest na piśmie wobec przyznania Śląska Cieszyńskiego Czechom.

Brak akceptacji dla polityki wschodniej Piłsudskiego (zwłaszcza zajęcia Wilna przez gen. Lucjana Żeligowskiego) oraz konflikty w łonie delegacji polskiej (m.in. spór z Askenazym odbierającym polecenia z Belwederu) skłoniły Paderewskiego do złożenia rezygnacji z funkcji I delegata RP na Zgromadzenie Ligi Narodów oraz stałego przedstawiciela rządu polskiego przy Lidze w dniu 7 maja 1921 r. Piłsudski odwołał go formalnie z tego stanowiska w dniu 23 maja $1921 \mathrm{r}$. Minister spraw zagranicznych Konstanty Skirmunt w liście do Paderewskiego zawiadamiającym go o przyjęciu jego dymisji, doceniając trudną misję delegata pisał: „Jednocześnie pozwalam sobie złożyć Panu najgłębsze dzięki za Jego świetną działalność na stanowisku powyższem, która w najwyższym stopniu przyczyniła się do utrwalenia i ugruntowania sprawy polskiej wobec Ligi Narodów, - za jego niezmordowaną i tak bardzo w wynikach owocną pracę, owianą, jak zawsze, jedynie tylko poczuciem niewyczerpanej ofiarności obywatelskiej oraz dążeniem do dobra i pomyślności Ojczyzny"88.

\footnotetext{
${ }^{84}$ Tamże, sygn, 789, s. 27.

85 Tamże, sygn. 867, s. 3.

86 Tamże, sygn. 789, s. 62.

87 Tamże, sygn. 928, s. 29.

88 AAN, AIJP, sygn. 867, s. 79. Taka sama pozytywna opinia działań Paderewskiego została wyrażona w styczniu 1921 r. przez poprzednika Skirmunta w MSZ, Eustachego Sapiehę. Zob. AAN, AIJP, sygn. 864, s. 323.
} 
Od tego momentu Paderewski podejmował przez kolejnych 20 lat szereg działań na rzecz sprawy polskiej już jako osoba prywatna. Do aktywności politycznej powrócił dopiero u schyłku swojego życia w 1939 r., do końca walcząc o polskie sprawy i zabiegając o uzyskanie pomocy w Stanach Zjednoczonych dla okupowanego kraju.

Krótki okres pełnienia przez Paderewskiego funkcji premiera rządu, obejmujący łącznie niecałe 11 miesięcy w 1919 r., przyniósł szereg ważnych zmian zarówno w kraju, jak i na arenie międzynarodowej. W polityce wewnętrznej rząd Paderewskiego we współpracy z Piłsudskim doprowadził do przeprowadzenia wyborów do Sejmu Ustawodawczego i uchwalenia tzw. Małej Konstytucji, która porządkowała sprawy naczelnych organów władzy i ustroju odrodzonego państwa. Rozpoczęto proces integracji państwa tworząc jednolitą administrację państwową, samorządową, skarbową i szkolną. Ogromne znaczenie dla prowadzonej walki o granice miała rozbudowa armii oraz jej wzmocnienie poprzez sprowadzenie do kraju ponad 60-tysięcznej Błękitnej Armii, sformowanej we Francji i dowodzonej przez gen. Józefa Hallera.

Efektem działań rządu na arenie międzynarodowej było doprowadzenie do uznania Polski za niepodległe państwo przez Stany Zjednoczone i państwa Europy Zachodniej. W wyniku aktywnej działalności Paderewskiego, na konferencji pokojowej w Paryżu uzyskano potwierdzenie międzynarodowego statusu Polski, traktowanej jako państwo sojusznicze Ententy. Dzięki kontaktom Paderewskiego w Stanach Zjednoczonych uruchomiono ogromną pomoc żywnościową, medyczną oraz finansową dla zniszczonego wojną kraju i setek tysięcy głodujących obywateli. Na czele Amerykańskiej Administracji Pomocy stał Herbert Hoover, w latach 19291932 prezydent Stanów Zjednoczonych. W 1922 r. w dowód wdzięczności za jego działalność nadano mu tytuł Honorowego Obywatela Rzeczypospolitej. W stulecie powstania gabinetu Ignacego Jana Paderewskiego w 2019 r. Sejm Rzeczypospolitej Polskiej podjął uchwałę, w której przypomniano jego zasługi w działaniach dyplomatycznych na arenie międzynarodowej oraz dokonania w polityce wewnętrznej ${ }^{89}$.

\title{
BIBLIOGRAFIA
}

\author{
ŹRÓDŁA ARCHIWALNE
}

Archiwum Akt Nowych

Zesp. 100, Archiwum Ignacego Jana Paderewskiego, sygn. 592, 609, 667, 745, 748, 789, 793, 841, $844,905,906,927,928,947,987,988,995,1364,1508$.

${ }^{89}$ Uchwała Sejmu Rzeczypospolitej Polskiej z dnia 22 lutego 2019 r. w sprawie uczczenia 100-lecia powstania gabinetu Ignacego Jana Paderewskiego, „Monitor Polski” z 7 marca 2019, nr 221. 
Zesp. 322, Ministerstwo Spraw Zagranicznych, sygn. 92, 207.

Zesp. 515, Biuro Prac Kongresowych, seria nr 4, sygn. 45-303.

Archiwum Instytutu Józefa Piłsudskiego w Nowym Jorku

Zesp. 2, Adiutantura Generalna Naczelnego Wodza, sygn. 105.

Zesp. 3, sygn. 2.

Archiwum Państwowe w Gdańsku

Zesp. 259, Komisarz Generalny Rzeczypospolitej w Gdańsku, seria 1, sygn. 8.

Archiwum Państwowe w Katowicach

Zesp. 27, Urząd Wojewódzki Śląski, sygn. 19.

Archiwum Narodowe w Krakowie

Zesp. 670, Zbiór Fotograficzny, sygn. 6082, 7846.

Archiwum Państwowe w Poznaniu

Zesp. 4807, Stanisław Nawrocki - spuścizna, sygn. 600, 1252, 1276, 1277.

Zesp. 4046, Zbiór pocztówek, sygn. 216.

Biblioteka Polska w Paryżu

Zesp. Kolekcja kartograficzna, Zbiór map z okresu prac Biura Kongresowego.

Centralne Państwowe Archiwum Historyczne Ukrainy we Lwowie

Zesp. 408, Греко-католицький митрополичий ординаріат, м. Львів (Greckokatolicki Ordynariat

Metropolitalny we Lwowie), opys 4, sygn. 574.

Instytut Polski i Muzeum im. gen. Sikorskiego w Londynie

Zesp. A.11, Ministerstwo Spraw Zagranicznych, nr podzespołu 49/Cz, sygn. 1.

Narodowe Archiwum Cyfrowe

Zesp. Koncern Ilustrowany Kurier Codzienny - Archiwum ilustracji, sygn. 1553.

Polish Music Center w Los Angeles

Zesp. Stojowski Collection, Mapa pt. Poland Eastern Theater of War.

\section{ŹRÓDŁA DRUKOWANE}

Archiwum polityczne Ignacego Paderewskiego, t. I: 18901918, oprac. W. Stankiewicz, A. Piber, Wrocław 1973; t. II: 191921, oprac. W. Stankiewicz, A. Piber, Wrocław 1974; t. III: 192134, oprac. H. Janowska i C. Madajczyk, Wrocław 1974; t. IV: 193540, oprac. T. Jędruszczak i A. Leinwand, Wrocław 1974; t. V: 1909-1941, wybór i oprac. A.G. Dąbrowski, M.M. Drozdowski (red. 
naukowy), K. Janczewska-Sołomko, M. Perkowska-Waszek, X. Pilch, Warszawa 2001; t. VI: 1915-1941, oprac. A.G. Dąbrowski, M.M. Drozdowski (red. naukowy), M. Perkowska-Waszek, X. Pilch, Warszawa 2007.

Haller Józef, Pamiętniki z wyborem dokumentów i zdjęć, wyd. 1, Londyn 1964, wyd. 2, Łomianki 2014. Helena Paderewska: Wspomnienia 1910-1920, oprac. M. Siekierski, Warszawa 2015.

Ignacy Jan Paderewski. Listy do Ojca i Heleny Górskiej (1872-1924), oprac. M. Perkowska-Waszek, red. M. Sułek, J. Szombara, Warszawa 2018.

Ignacy Jan Paderewski. Myśli o Polsce i Polonii, oprac. M. M. Drozdowski, A. Piber, Paris 1992.

JoNCA K., Wojna polsko-sowiecka 1920 roku w dokumentach niemieckiej dyplomacji, Wrocław 2002.

Nieznana korespondencja arcybiskupów metropolitów lwowskich Józefa Bilczewskiego z Andrzejem Szeptyckim w czasie wojny polsko-ukraińskiej 1918-1919, oprac. J. Wołczański, Lwów-Kraków 1997.

Sprawy polskie na konferencji pokojowej w Paryżu w 1919 r. Dokumenty i materiały, red. R. Bierzanek, J. Kukułka, t. I-III, Warszawa 1965-1968.

Uchwała Sejmu Rzeczypospolitej Polskiej z dnia 22 lutego 2019 r. w sprawie uczczenia 100-lecia powstania gabinetu Ignacego Jana Paderewskiego, „Monitor Polski” z 7 marca 2019, nr 221.

Митрополит Андрей Шептицький. Життя і діяльність. Документи і матеріали 1899-1944, Львів 1998-1999, т. 2, кн. 2.

\section{OPRACOWANIA}

DAvies N., Orzeł bialy, gwiazda czerwona. Wojna polsko-bolszewicka 1919-1920, Kraków 1997.

DĄBRowski A., Archiwum Ignacego Jana Paderewskiego z lat 1861-1941 przechowywane w zasobie Archiwum Akt Nowych - tylko online na stronie: http://cennebezcenne.pl/wp-content/ uploads/2018/05/DABROWSKI-www.pdf

DrozDowsKi M.M., O niepodległa i demokratyczna Rzeczpospolita. Z dziejów aktywności artystycznej i obywatelskiej Ignacego Jana Paderewskiego, Kraków-Warszawa 2018.

Drozdowski M.M., Ignacy Jan Paderewski - wspóttwórca Niepodległej, Warszawa 2017.

DrozDowski M.M., Ignacy Jan Paderewski. Zarys biografii politycznej, wyd. 2 poprawione, Warszawa 1981.

Drozdowski M.M., Paderewski w latach II wojny światowej, „Więź”, 1986, nr 5/6, s. 175-188.

Goclon J., Paderewski jako Prezes Rady Ministrów (16 stycznia - 9 grudnia 1919), „Czasopismo Prawno-Historyczne", 63(2011), z. 1, s. 221-245.

Goclon J., Rząd Ignacego Paderewskiego. Geneza, skład osobowy i działalność (16 stycznia 1919 9 grudnia 1919), „Acta Universitatis Lodziensis”, Folia Historica, 86, 2011, s. 94-145.

Goclon J., Próby reform i dokonania gabinetu Ignacego Paderewskiego w świetle protokołów posiedzeń Rady Ministrów (16 stycznia - 9 grudnia 1919 r.), cz. 1, „Słupskie Studia Historyczne” 2015, nr 19, s. 133-171.

Gónny M., Karty na stół. Geografia i granice nowej Europy po I wojnie światowej, „Kwartalnik Historyczny", 125(2018), z. 2, s. 427-469.

GóRski R., Archiwum Ignacego Jana Paderewskiego. Proces aktotwórczy i archiwizacja, „Teki Archiwalne. Seria Nowa", t. 11 (33), 2011, s. 345-362.

Halski Cz., Ignacy Jan Paderewski. Dzieje wielkiego Polaka i wielkiego Europejczyka, London 1964. KonopCZYŃski W., Dziennik 1918-1921, cz. 1, oprac. P. Biliński, P. Plichta, Warszawa-Kraków 2016. 
Krochmal A., Król pianistów w świecie polityki. Ignacy Jan Paderewski w dokumentach archiwalnych, Warszawa 2019.

Landau R., Paderewski, London 1934, Warszawa 1935.

Lisiak H., Paderewski. Od Kuryłówki po Arlington, Poznań 1992.

MatuszeK E., Akt pamiątkowy objęcia Górnego Śląska przez Rząd Rzeczypospolitej Polskiej. Dzieje jednego dokumentu, Katowice 2019.

OlczaK M., Ignacy Jan Paderewski 1860-1941, Warszawa 2018.

OpieŃski H., Ignacy Jan Paderewski, Warszawa 1928.

Orıowski J., Ignacy Jan Paderewski i odbudowa Polski, t. I-II, Chicago 1939-1940.

Paderewski. Anatomia geniuszu, Warszawa 2018.

Paderewski. Katalog wystawy, Muzeum Narodowe w Warszawie, 17 lutego - 20 maja 2018, red. J. Bojarska-CiEśLıK, M. Pinker, J. Popkowska, Warszawa 2018.

Pamięć Polski. Dokumenty Niepodległej. Wystawa III edycji Polskiej Listy Krajowej Programu UNESCO Pamięć Świata. Wydanie specjalne z okazji XX Powszechnego Zjazdu Historyków Polskich w Lublinie, 18-20 września 2019 r., Warszawa 2019.

Perkowska M., Diariusz koncertowy Ignacego Jana Paderewskiego, Kraków 1990.

PerkowsKa-Waszek M., Ignacy Jan Paderewski o sobie. Zarys biografii wzbogacony listami artysty, Tarnów-Kąśna Dolna 2004.

PerkowsKa-Waszek M., Paderewski i jego twórczość. Dzieje utworów i rys osobowości kompozytora, Kraków 2010.

Perkowska-Waszen M., Za kulisami wielkiej kariery. Paderewski w dziennikach i listach Sylwina i Anieli Strakaczów 1936-1937, Kraków 1994.

PHILLIPS Ch., The Story of a Modern Immortal, New York 1933.

Piber A., Archiwum Ignacego Jana Paderewskiego, „Archeion”, t. 39(1963), s. 63-86.

Piber A., Droga do stawy. Ignacy Paderewski w latach 1860-1902, Warszawa 1982.

Pilat T., Podręcznik statystyczny Galicji, t. IX, cz. 1, Lwów 1913.

PrZYBYLSKi H., Paderewski. Między muzyka a polityka, Katowice 1992.

RaDZiwillowicz D., Btękitna Armia. W 80. rocznicę utworzenia, Warszawa 1997.

Romer E., Geograficzno-statystyczny atlas Polski, Warszawa-Kraków 1916.

Romer E., Pamiętnik paryski (1918-1919), oprac. A. Garlicki, R. Świętek, Wrocław 1989.

Suleja W., Ignacy Jan Paderewski, premier Republiki Polskiej 16 I- 9 XII 1919, w: Prezydenci i premierzy Drugiej Rzeczypospolitej, red. A. Chojnowski, P. Wróbel, Wrocław 1992.

Szymczak D., Najważniejszy gość Bazaru. Paderewski, Bazar i powstanie wielkopolskie, „Kronika Miasta Poznania", 2015, nr 4, s. 140-158.

Ślask Cieszyński od Wiosny Ludów do I wojny światowej w latach 1848-1918, red. I. Panic, K. Nowak, Cieszyn 2013.

Śląsk Cieszyński w latach 1918-1945, red. K. Nowak, Cieszyn 2015.

Wanatowicz M., Historia społeczno-polityczna Górnego Ślaska i Ślaska Cieszyńskiego w latach 1918-1945, Katowice 1994.

WAPIŃSKI R., Ignacy Paderewski, Wrocław 1999.

WeINFELD I., Ludność miejska Galicyi i jej skład wyznaniowy (1881-1910), „Wiadomości Statystyczne o stosunkach krajowych wydawane przez Krajowe Biuro Statystyczne”, red. T. Pilat, t. XXIV, z. II, Lwów 1912. 
WnęTRZAK G., Stosunki polityczne i narodowościowe na pograniczu Śląska Cieszyńskiego i Galicji Zachodniej w latach 1897-1920, Torun 2014.

Zamoyski A., Paderewski, Warszawa 1992.

Zamoyski A., Warszawa 1920. Nieudany podbój Europy. Klęska Lenina, Kraków 2009.

Zespoły akt do dziejów powstań śląskich i plebiscytu na Górnym Śląsku z lat 1918-1950 w zasobie Archiwum Państwowego w Katowicach, oprac. E. Długajczyk, P. Greiner, S. Krupa, Katowice 2011. ŻEbrowski M., Paderewski w Kalifornii, Torun 2018.

Żurawski vel Grajewski P.P., Sprawa ukraińska na konferencji pokojowej w Paryżu w roku 1919, Warszawa 2017.

Державний архів Житомирської области. Анотований реєстр описів. Фонди дворянського nеріоду, Житомир 2009.

\author{
“KEYBOARD WIZARD” IN THE WORLD OF DIPLOMACY \\ THE ROLE OF IGNACE JAN PADEREWSKI \\ IN THE FIGHT FOR POLISH BORDERS (1919-1920)
}

\begin{abstract}
Ignace Jan Paderewski (1860-1941) - a world-famous pianist, composer, politician, statesman and diplomat played a significant role in shaping the reborn Polish state and its borders. $\mathrm{He}$ undertook active political activity during the First World War. In the years 1915-1918, he acquired the President of the United States, Woodrow Wilson and his closest associates, as well as over 4 million American Polonia for the Polish cause. He gained real influence on the shaping of the territory and borders of the Polish state after taking office as the Prime Minister of the Polish Government and the Minister of Foreign Affairs. This took place on January 16, 1919. Paderewski led to the recognition of the reborn Polish state in the international arena by the United States (January 30, 1919), France (February 23), Great Britain (February 25), Italy (February 27), and then other countries. He represented Poland in Paris as a delegate to the peace conference. During the several months of deliberations he fought for the incorporation into the Polish state of Eastern Galicia, Cieszyn Silesia and Upper Silesia, as well as Gdańsk together with Pomerania. He was supported in these activities by well-known Polish scholars, both historians (Szymon Askenazy, Oskar Halecki, Władysław Konopczyński) and geographers (Eugeniusz Romer). Together with Roman Dmowski, he signed at Versailles on 28 June 1919 a peace treaty ending World War I. After resigning from the post of prime minister on December 9, 1919 and leaving the country, he was still interested in Polish affairs. He returned to political activity during the Bolshevik invasion of Poland. From July 1920 to May 1921, at the request of the Polish government and the head of state Józef Piłsudski, he was a Polish delegate to international conferences and a representative at the League of Nations.
\end{abstract}

Keywords: Ignace Jan Paderewski; Paris Peace Conference; Treaty of Versailles; Silesian Uprisings; Eastern Galicia; Cieszyn Silesia; Upper Silesia; Free City of Gdańsk. 


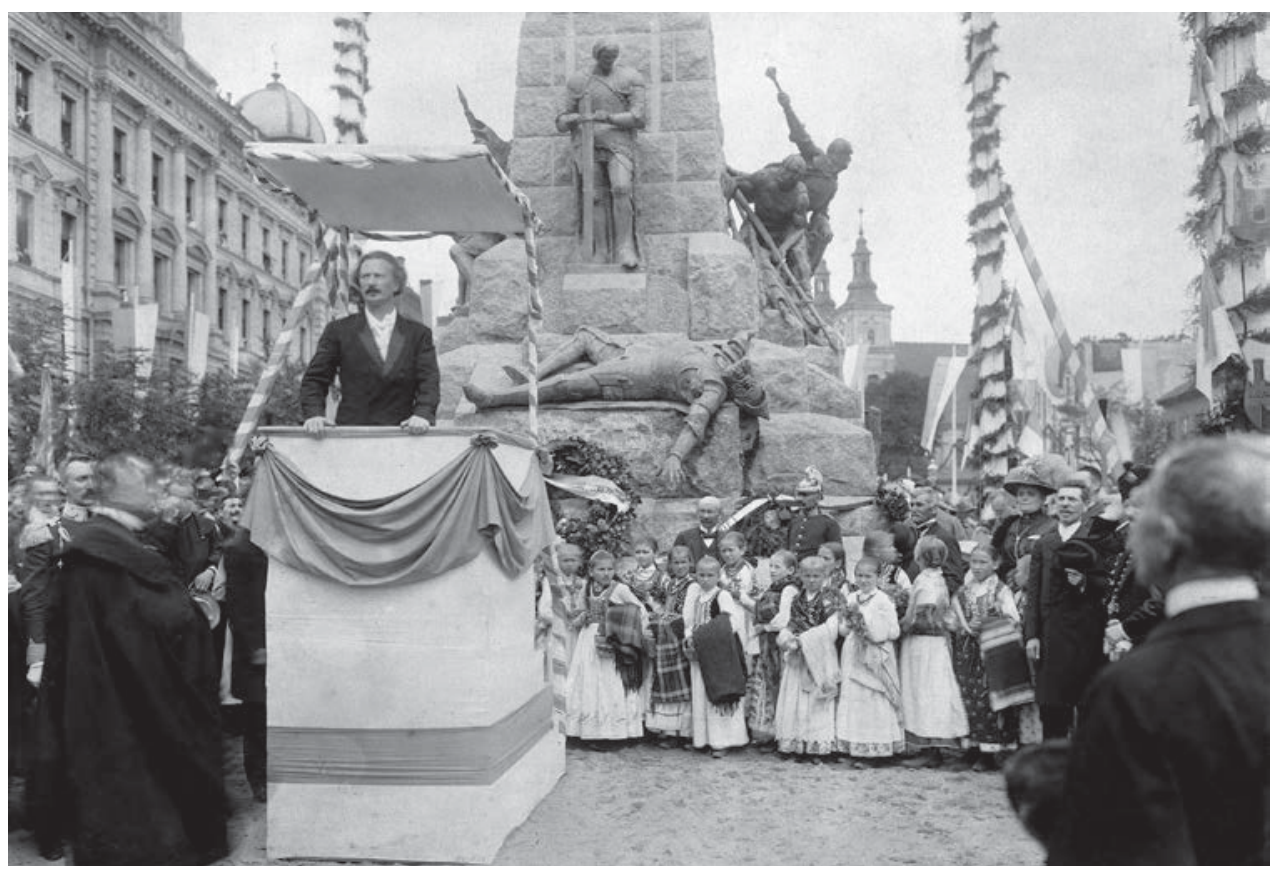

1. Ignacy Jan Paderewski podczas przemówienia na uroczystości odsłonięcia pomnika w 500. rocznicę bitwy pod Grunwaldem, Kraków, 15 lipca 1910 r. (z zasobu Archiwum Narodowego w Krakowie)

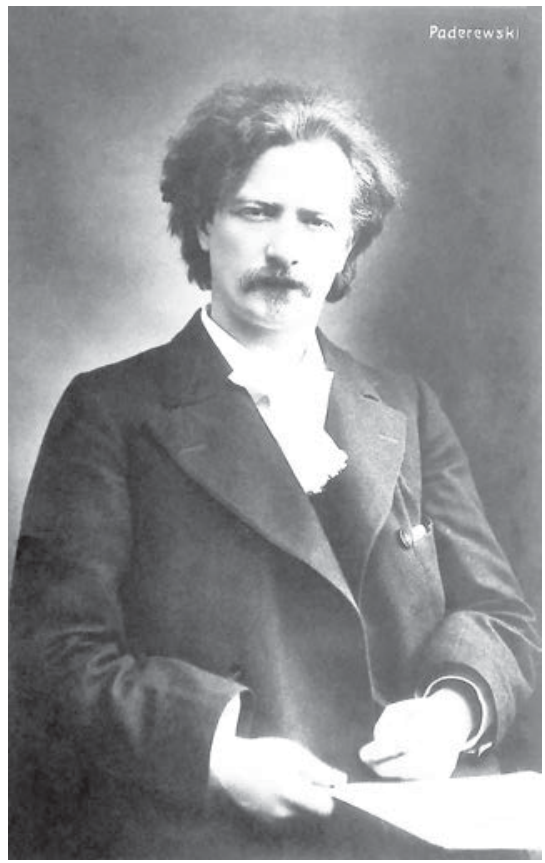

2. Fotografia portretowa Paderewskiego (z zasobu Archiwum Akt Nowych) 


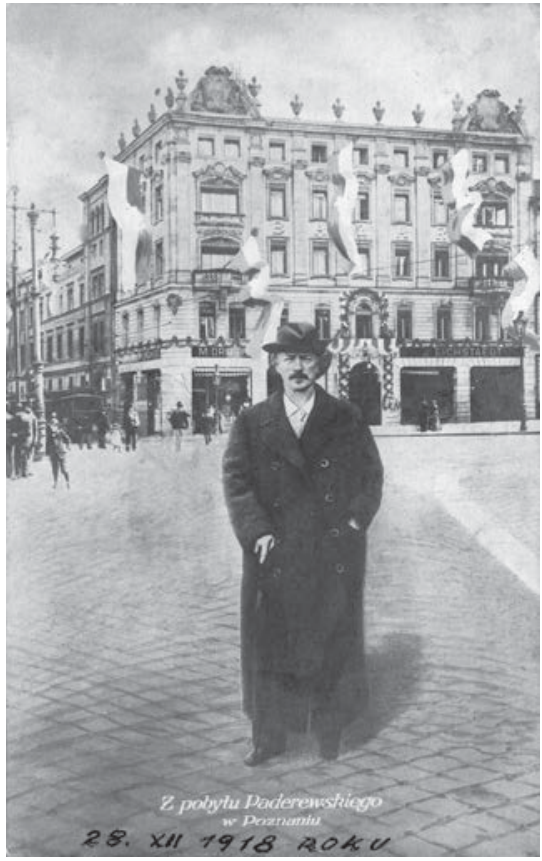

\section{Ignacy Paderewski}

przed hotelem Bazar w Poznaniu, grudzień $1918 \mathrm{r}$. (z zasobu Archiwum Państwowego w Poznaniu)

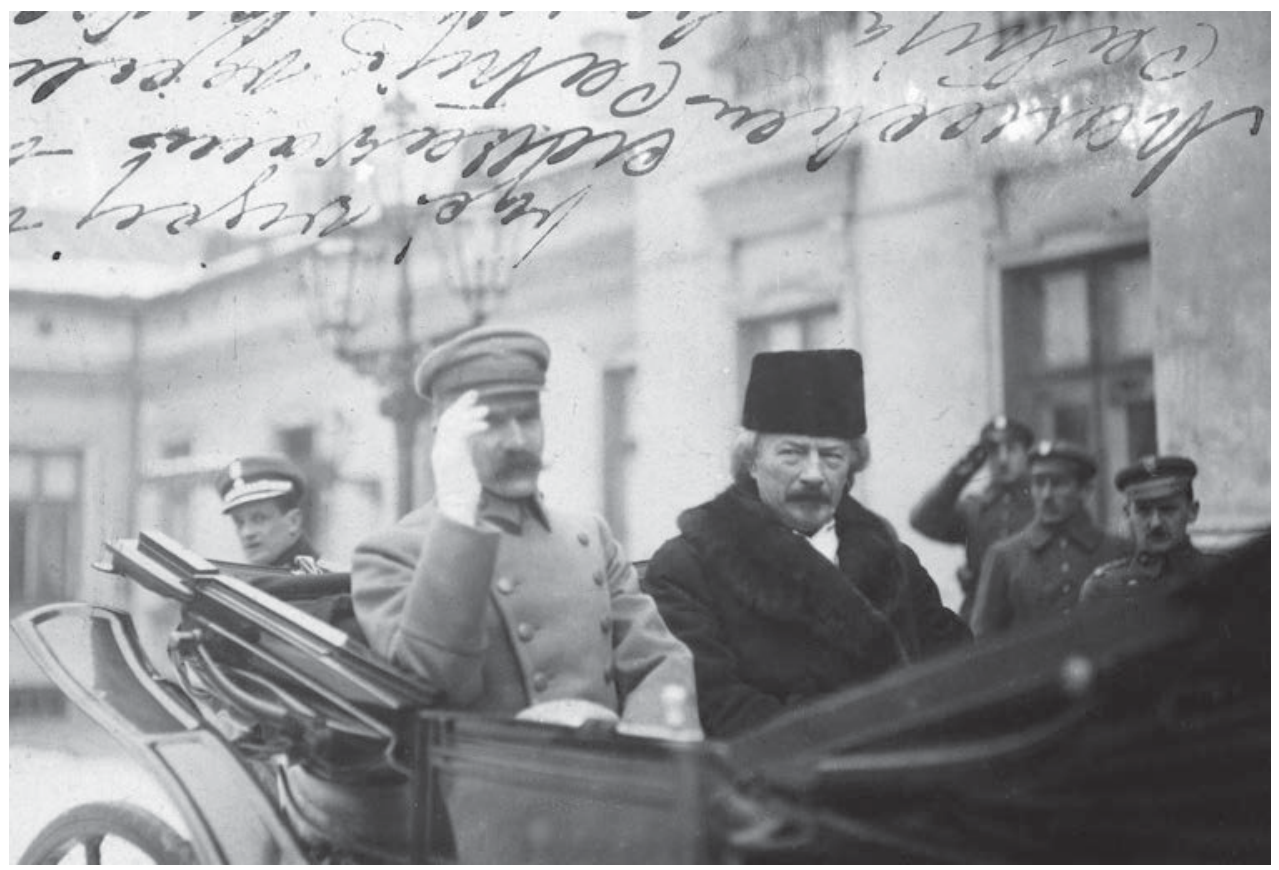

4. Naczelnik państwa Józef Piłsudski i premier Ignacy Paderewski w drodze na obrady Sejmu Ustawodawczego, 10 lutego 1919 r. (z zasobu Archiwum Narodowego w Krakowie) 


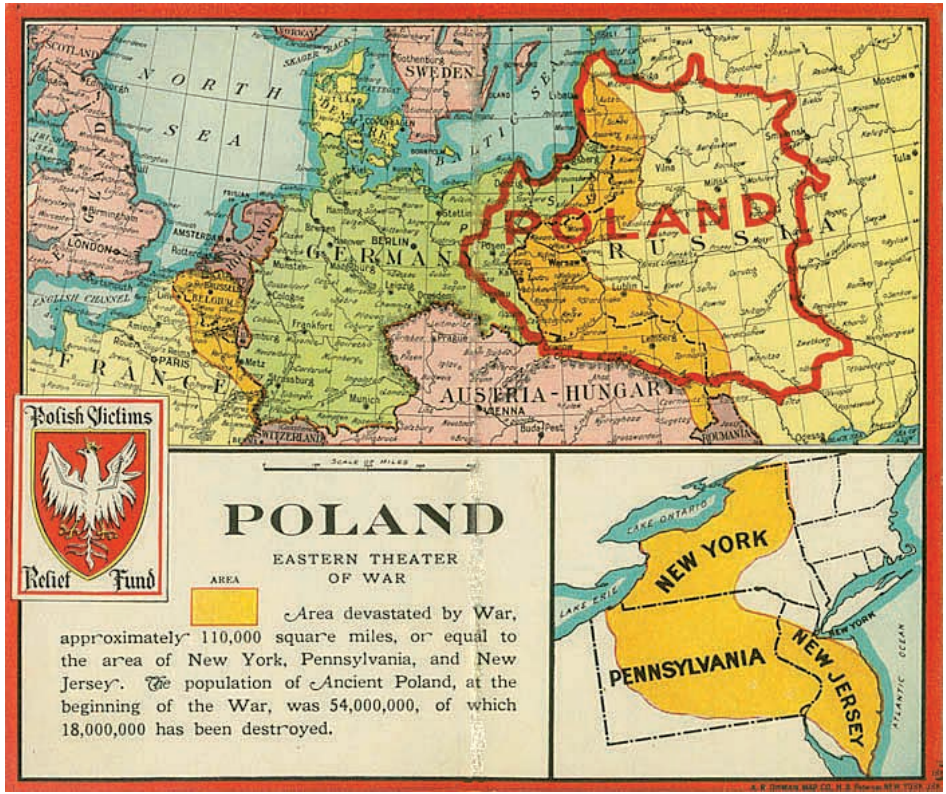

5. Mapa obrazująca zniszczenia wojenne na ziemiach Polski w zestawieniu z terytorium kilku stanów USA, ok. 1917 r.

(ze zbiorów Polish Music Center w Los Angeles)

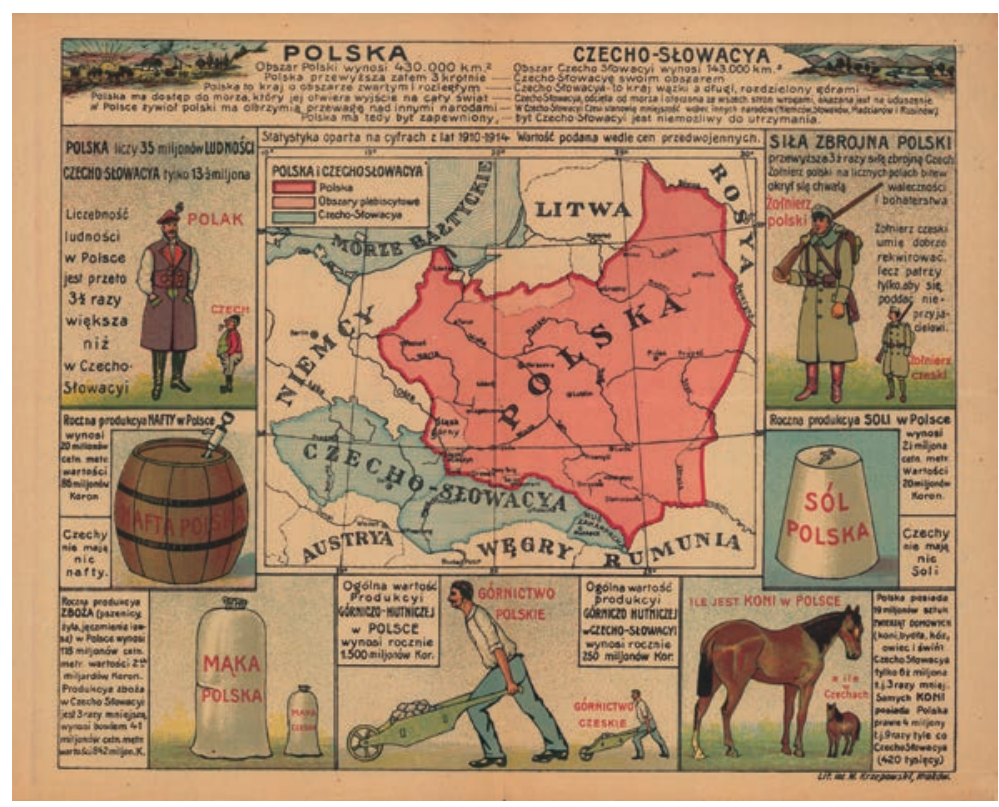

6. Plakat propagandowy z okresu plebiscytu na Śląsku Cieszyńskim (z zasobu Archiwum Narodowego w Krakowie) 


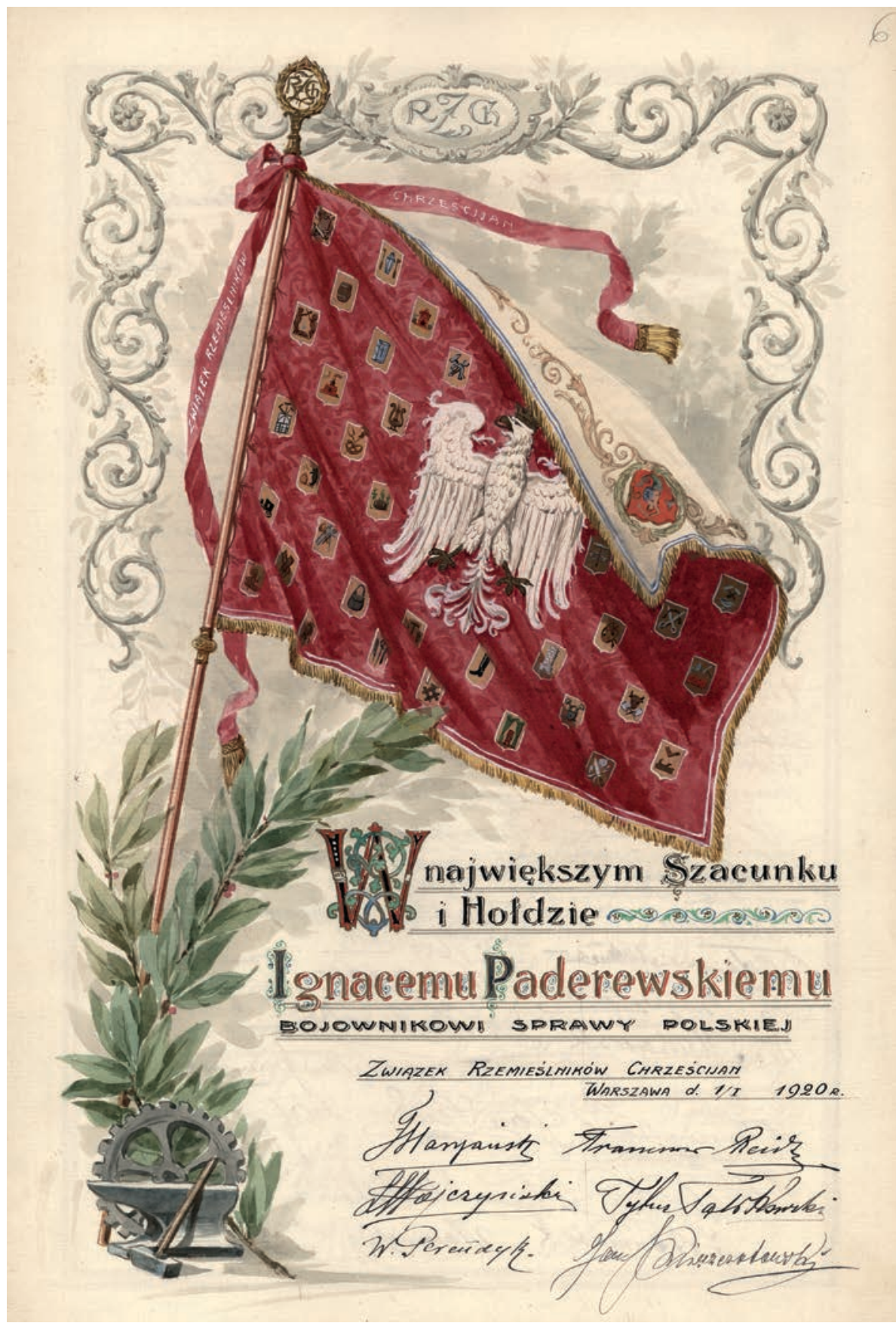

7. Dyplom od Związku Rzemieślników Chrześcijan w Warszawie z podziękowaniem dla Paderewskiego po jego dymisji z funkcji premiera rządu 1 stycznia 1920 r. (z zasobu Archiwum Akt Nowych w Warszawie) 